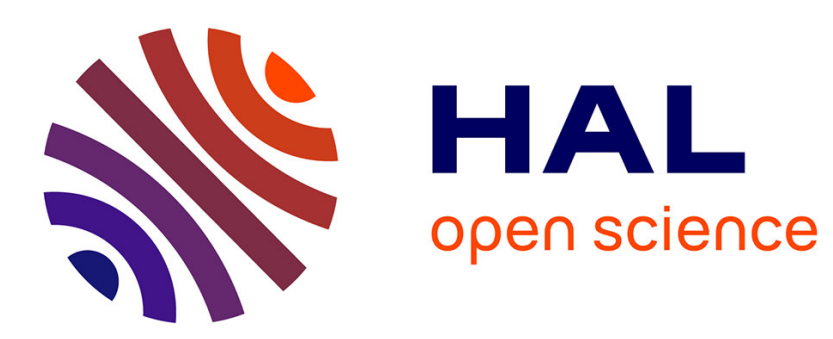

\title{
High-resolution simulations of the surface mass balance of Greenland at the end of this century \\ G. Krinner, N. Julien
}

\section{To cite this version:}

G. Krinner, N. Julien. High-resolution simulations of the surface mass balance of Greenland at the end of this century. The Cryosphere Discussions, 2007, 1 (2), pp.351-383. hal-00331151

\section{HAL Id: hal-00331151 \\ https://hal.science/hal-00331151}

Submitted on 10 Sep 2007

HAL is a multi-disciplinary open access archive for the deposit and dissemination of scientific research documents, whether they are published or not. The documents may come from teaching and research institutions in France or abroad, or from public or private research centers.
L'archive ouverte pluridisciplinaire HAL, est destinée au dépôt et à la diffusion de documents scientifiques de niveau recherche, publiés ou non, émanant des établissements d'enseignement et de recherche français ou étrangers, des laboratoires publics ou privés. 


\section{High-resolution simulations of the surface mass balance of Greenland at the end of this century}

G. Krinner and N. Julien

LGGE/CNRS-UJF Grenoble, France

Received: 30 August 2007 - Accepted: 7 September 2007 - Published: 10 September 2007

Correspondence to: G. Krinner (krinner@ ujf-grenoble.fr)

Greenland surface mass balance at the end of this century

G. Krinner and N. Julien

Title Page

Abstract Introduction

Conclusions References

Tables Figures

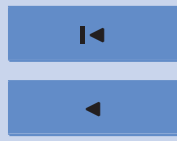
$\rightarrow 1$

Back Close 


\section{Abstract}

We present atmospheric general circulation model simulations of the present (19812005) and future (2081-2100) climate according to the SRES A1B greenhouse gas scenario. Focusing on Greenland, we use a stretched grid in the global model, thereby

5 reaching a horizontal grid spacing of $60 \mathrm{~km}$ in the region of interest. This allows to capture reasonably the escarpment zone of the ice sheet. For the end of this century, the model suggests a precipitation increase in the central region of Greenland, which is overcompensated for by a strong increase of meltwater production in the lower areas. We calculate the changes of water fluxes into the adjacent seas according the simulated surface mass balances changes. The calculated freshwater flux at the end of the 21 st century appears too weak to induce a significant reduction of the meridional overturning circulation in the North Atlantic. The resulting surface mass balance decrease between the last decades of the 20th and 21st centuries is equivalent to a positive contribution of $0.8 \mathrm{~mm} \mathrm{yr}^{-1}$ to global eustatic sea-level rise.

\section{Introduction}

Rapid changes in the altitude of the surface of Greenland are currently being observed. A review by Cazenave (2006) showed that more recent satellite measurements tend to indicate higher rates of mass loss than older ones. In particular, satellite gravity surveys indicate a recent acceleration of ice mass loss (Velicogna and Wahr, 2006; Chen et al., 2006), probably localized in low-lying areas (Luthcke et al., 2006) and concentrated in the south (Velicogna and Wahr, 2006). This is coherent with older measurements indicating rapid ice marginal changes (e.g., Krabill et al., 1999; Zwally et al., 2005; Alley et al., 2005) and thickening in the interior (Zwally et al., 2005; Johannessen et al., 2005). The rapid, accelerating ice loss in the marginal areas seems to be partially

25 a consequence of rapidly increasing ice flow rates (e.g., Krabill et al., 2004; Rignot and Kanagaratnam, 2006), which may be linked to increased basal lubrication as a

Greenland surface mass balance at the end of this century

G. Krinner and N. Julien

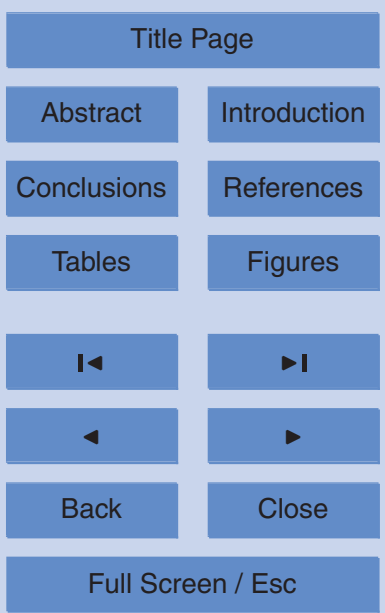

Printer-friendly Version

Interactive Discussion 
consequence of surface melt intensification (Zwally et al., 2005) or the disintegration of floating ice tongues which reduces their buttressing effect (De Angelis and Skvarca, 2003). Another cause of the observed coastal thinning appears to be a significant increase in surface melt rates (Krabill et al., 2004; Fettweis et al., 2007).

5 The mass loss of the Greenland ice sheet is more rapid than previously expected, suggesting that previous estimates of future sea-level rise might be too low (Dowdeswell, 2006). Indeed, a simple semi-empirical model linking global temperature to sea-level (Rahmstorf, 2007) would suggest the possibility of more rapid sea-level rise than projected by the IPCC 2001; 2007, which could point to a higher sensitivity of ice-sheet

10 mass balances to climate changes, and an aggressive interpretation of available palaeoclimatic evidence suggests similar conclusions (Overpeck et al., 2006). However, this latter approach has been severely criticized (Oerlemans et al., 2006).

In the 1990s, coupled atmosphere-ocean general circulation model (GCM) studies of $2 \times \mathrm{CO}_{2}$ climates have been analyzed with respect to the Greenland surface mass 15 lated Greenland SMB change would induce a sea-level rise of $1.3 \mathrm{~mm} / \mathrm{yr}$. In a similar study, Ohmura et al. (1996) analysed a T106 integration with the ECHAM GCM, which yields a SMB change equivalent to a $1.1 \mathrm{~mm} / \mathrm{yr}$ sea-level rise. A study with a more recent version of this GCM and with a slightly modified method to calculate melt rates yielded a less dramatic melt rate increase under a transient climate change (following the IS92a greenhouse gas emission scenario) at the time of the doubling of the $\mathrm{CO}_{2}$ concentrations with respect to preindustrial values. Combined with an expected increase of precipitation in the interior, this lead Wild et al. (2003) to predict an increase of the Greenland SMB under transient $2 \times \mathrm{CO}_{2}$ conditions. Kiilsholm et al. (2003) conducted a high-resolution $(50 \mathrm{~km})$ study with the HIRHAM regional climate model, which was forced at its lateral boundaries by the ECHAM4OPYC3 coupled model under the SRES A2 and B2 scenarios. In both scenarios, HIRHAM results differ considerably from those of the driving model; in particular, the estimated melt rates are higher in HIRHAM. Under both greenhouse gas emissions scenarios, both the HIRHAM and the
Greenland surface mass balance at the end of this century

G. Krinner and N. Julien

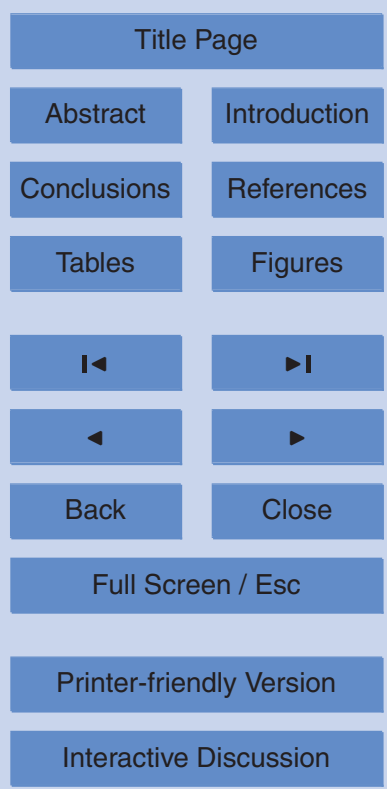

EGU 
driving model simulate negative Greenland surface mass balances at the end of this century.

In a more general multi-model approach, Gregory and Huybrechts (2006) show that a global temperature change exceeding $3^{\circ} \mathrm{C}$, combined with the associated precipita5 tion changes, would lead to a negative surface mass balance of the Greenland ice sheet. This means that under most realistic greenhouse gas emission scenarios, the Greenland SMB might become negative by 2100 , meaning that the ice sheet will disappear in the long term if the climate does not recover to its present-day state (Gregory et al., 2004).

10 Here we present a new model study of the future (2081-2100) surface mass balance of the Greenland ice sheet under the SRES A1B greenhouse gas emission scenario. This study is carried out at high resolution $(60 \mathrm{~km})$ with a stretched-grid GCM and therefore combines some advantages of a global model (e.g., two-way interactions between the climate change in the region of interest and the rest of the atmosphere) with those

of a regional model (in particular, high resolution at a reasonable numeric cost). The paper is organized as follows. Section 2 presents the model, the experimental setup and the methods used to calculate the different components of the surface mass balance. Section 3 rapidly compares the simulated present-day surface climate to available observations and presents the simulated changes in the various mass balance components. The discussion in Sect. 4 analyses the causes of the simulated precipitation changes and the potential large-scale impact of the simulated SMB changes.

\section{Methods}

We used the LMDZ4 atmospheric general circulation model (AGCM; Hourdin et al., 2006) forced by SRES A1B greenhouse gas (GHG) concentrations for the period 2080 25 to 2100 , and by observed GHG concentrations for the period 1980 to 2005 . The simulation for the two final decades of the 20th century and the first five years of the 21st century was forced by observed oceanic boundary conditions (sea-surface temper-

Greenland surface mass balance at the end of this century

G. Krinner and N. Julien

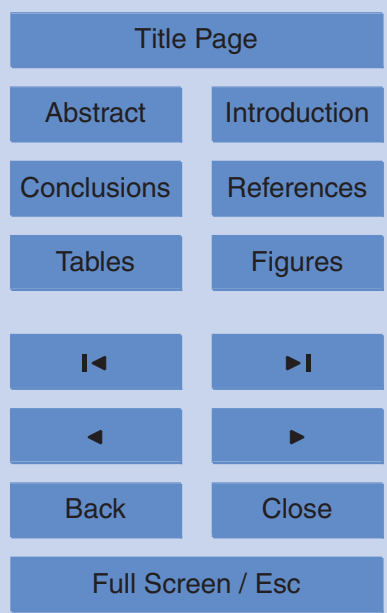

Printer-friendly Version

Interactive Discussion 
ature [SST] and sea-ice concentrations [SIC]), while future oceanic boundary conditions are obtained by superimposing observed present-day oceanic conditions and an oceanic climate change signal from the SRES-A1B coupled model run with the IPSLCM4 ocean-atmosphere general circulation model (Marti et al., 2005), of which the

5 AGCM used here is the atmospheric component. The climate sensitivity of IPSL-CM4 for a doubling of the atmospheric $\mathrm{CO}_{2}$ concentration from preindustrial values $\left(3.7^{\circ} \mathrm{C}\right)$ is situated in the upper part of the range of coupled models of the 4th IPCC assessment report (Forster and Taylor, 2006). The anomaly method used for constructing the future oceanic boundary conditions is described in detail in Krinner et al. (2007). Using 10 the grid-stretching facility of LMDZ4 (Krinner et al., 1997), the AGCM is run with a high regional resolution of up to $60 \mathrm{~km}$ over Greenland. The first year of the two model runs is discarded as spin-up, leaving for analysis the years 1981 to 2005 and 2081 to 2100 , respectively.

Because melt rates on the margin of the ice sheet can be high, significant runoff is 15 generated from this ice sheet, as opposed to Antarctica, where the overwhelming part of surface melt water refreezes (Liston and Winther, 2005). Even at the fairly high resolution of $60 \mathrm{~km}$, the model will not correctly resolve the ablation zone of the ice sheet. For this reason, we use an empirical relationship linking summer (JJA) air temperature and annual meltwater runoff proposed by Ohmura et al. (1996). This method takes into account meltwater production and refreezing. It consists of interpolating the simulated surface air temperature on a fine grid, using the difference between a high-resolution surface topography (Ekholm, 1996) and the surface elevation at the model resolution to correct the surface air temperature. A model study by Krinner and Genthon (1999) suggests that the sensitivity of surface air temperature to elevation changes in summer 25 near the Greenland ice sheet margin is about $-6^{\circ} \mathrm{C} / \mathrm{km}$. This value is used here to calculate the summer air temperature at the high resolution of the topographic database (we use a downgraded version with a resolution of $10 \mathrm{~min}$ ). The linear relationship between summer surface air temperature and meltwater runoff as proposed by Ohmura et al. (1996) is then applied to these high-resolution surface air temperature results.

\section{Greenland surface mass balance at the end of this century}

G. Krinner and N. Julien

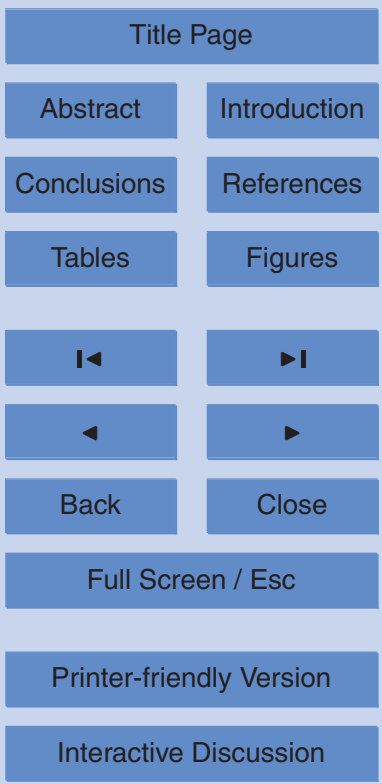


In calculating the surface mass balance, the fraction of rainfall that freezes on the ice sheet, thus positively contributing to accumulation, needs to be estimated. We reason that the fraction $f_{f}$ of the rainfall which freezes in the snow pack will be approximately equal to the fraction of meltwater that refreezes, as this fraction depends on the physi5 cal characteristics of the snow pack, and meltwater and liquid precipitation occur during the same season. This fraction can be calculated from the ratio between the estimated meltwater runoff $R_{M}$ (following Ohmura et al. (1996); see preceding paragraph) and the total surface melt $M$ simulated by the GCM: $f_{f}=1-R_{M} / M$. The surface mass balance $B$ is then evaluated as $B=S+f_{f} L-E-R_{M}$, where $S$ stands for solid precipitation,

$10 L$ for liquid precipitation, $E$ for evaporation (or sublimation), and $R_{M}$ is the meltwater runoff. The total ice sheet runoff is then $R=R_{M}+\left(1-f_{f}\right) L$. We define accumulation as $A=S+f_{f} L$, that is, as the part of the total precipitation that does not immediately run off the ice sheet.

Blowing snow and its sublimation are not represented in this model, although Box 15 et al. (2004) have suggested that blowing snow sublimation might amount to $6 \%$ of the mean precipitation on the ice sheet.

\section{Results}

\subsection{Present-day climatology}

Figure 1 displays the annual mean of the absolute monthly surface air temperature

bias, calculated as $\beta=\overline{\left|T_{\text {obs }, i}-T_{\text {mod }, i}\right|}$ ( $\left.i=1 \ldots 12\right)$ (the overline denotes the time mean) in the present-day simulation. The observed temperatures $\left(T_{\text {obs }}\right)$ were obtained from Greenland Climate network (GC-Net) automatic weather stations (Steffen, 2005) and WMO manned weather stations. The annual mean absolute monthly surface air temperature bias below $2^{\circ} \mathrm{C}$ for most stations, which is fairly low. However, larger biases do occur locally, in particular in the north-east of Greenland, where the model significantly overestimates the surface air temperatures in winter. This warm bias in winter does

Greenland surface mass balance at the end of this century

G. Krinner and N. Julien

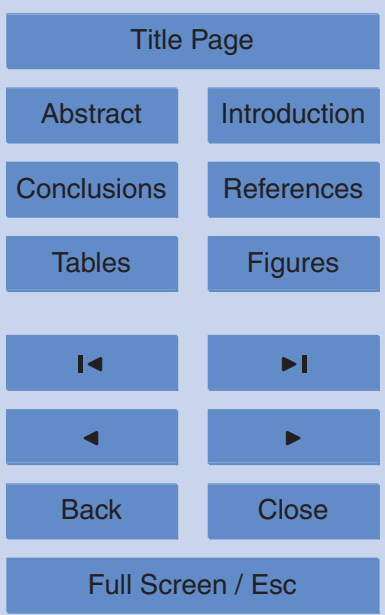

Printer-friendly Version

Interactive Discussion 
not appear to be induced by erroneous circulation patterns, as neither the $500 \mathrm{hPa}$ height (Fig. 2a) nor the sea level pressure distribution (not shown) would induce an anomalous southerly flow in this area.

Figure 2 compares the simulated winter (DJF) and summer (JJA) $500 \mathrm{hPa}$ height to 5 the NCEP analysis for the same period. In summer, the model errors are fairly weak, and vanish over the region of interest. The winter errors are more significant, but not dramatic. The positive bias over Greenland (between $10 \mathrm{~m}$ in the south-west and $80 \mathrm{~m}$ in the north-east) might be linked to the warm winter bias near the surface mentioned in the preceding paragraph.

10 The mean precipitation over the ice sheet is $316 \mathrm{~kg} \mathrm{~m}^{-2} \mathrm{yr}^{-1}$. This is in fairly good agreement with the long-term mean precipitation of $346 \mathrm{~kg} \mathrm{~m}^{-2} \mathrm{yr}^{-1}$ estimated from glaciological data (Ohmura and Reeh, 1991; Ohmura et al., 1999).

The simulated cumulated melt area for the years 1981 to 2005 is displayed in Fig. 3. The cumulated melt area is defined as the annual total sum of the daily ice sheet 15 melt areas (Fettweis et al., 2007). The mean simulated cumulated melt area, about $29 \times 10^{6} \mathrm{~km}^{2}$, compares well with the satellite-based, model-corrected ImpXPGR data given by (Fettweis et al., 2007, their Fig. 2). However, LMDZ4 only simulates a weak positive trend of $+0.1 \times 10^{6} \mathrm{~km}^{2} / \mathrm{yr}$ between 1981 and 2005 and thus underestimates the observed positive trend of $+0.5 \times 10^{6} \mathrm{~km}^{2} / \mathrm{yr}$ given by Fettweis et al. (2007). Figure $4 \mathrm{a}$ displays the simulated number of days with snow melt per year. The extent of the meltfree area in the centre of the ice sheet is in excellent agreement with the satellite-based data given by Fettweis et al. (2007).

The simulated surface mass balance for the period 1981-2005, using the ablation parametrization by Ohmura et al. (1996), is shown in Fig. 5a. The average simulated 25 mean surface mass balance over the ice sheet is $109 \mathrm{~kg} \mathrm{~m}^{-2} \mathrm{yr}^{-1}$ (corresponding to $\left.202 \mathrm{~km}^{3} \mathrm{yr}^{-1}\right)$, which is in fair agreement with the best estimate of $(134 \pm 24) \mathrm{kg} \mathrm{m}^{-2} \mathrm{yr}^{-1}$ given by IPCC (2001). If the model-simulated surface melt is used together with the refreezing parametrizationation of Pfeffer et al. (1991), as done for Antarctica by Krinner et al. (2007), the integrated surface mass balance is reduced to $+8 \mathrm{~kg} \mathrm{~m}^{-2} \mathrm{yr}^{-1}$.

Greenland surface mass balance at the end of this century

G. Krinner and N. Julien

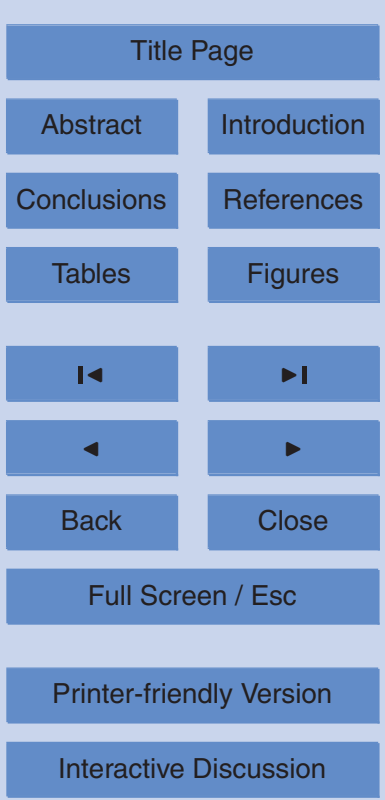

EGU 
The difference, $101 \mathrm{~kg} \mathrm{~m}^{-2} \mathrm{yr}^{-1}$, essentially results from an increase of the estimated meltwater runoff $\left(+83 \mathrm{~kg} \mathrm{~m}^{-2} \mathrm{yr}^{-1}\right)$, the remainder being due to an increase of the estimated rainwater runoff $\left(+18 \mathrm{~kg} \mathrm{~m}^{-2} \mathrm{yr}^{-1}\right)$, both resulting from high simulated melt rates. As explained before, the method of Ohmura et al. (1996) appears preferable because 5 of the insufficient resolution of the GCM. Moreover, as will be seen in Sect. 4.1, using the Ohmura et al. (1996) parametrization yields a present-day simulated surface mass balance which is in good agreement with available ice-sheet average estimates.

The geographical distribution of the simulated surface mass balance corresponds to the observed patterns (Ohmura and Reeh, 1991; Ohmura et al., 1999; Dethloff et al.,

10 2002) and previous model studies (e.g., Bromwich et al., 1999; Dethloff et al., 2002; Box et al., 2004; Fettweis et al., 2005), the highest values occurring in the south-east, and a secondary maximum appearing on a band at the western side of the ice sheet at intermediate elevation.

\subsection{Surface mass balance change during the 21st century}

15 The simulated mean surface mass balance of the Greenland ice sheet for the period 2081-2100 is $-51 \mathrm{~kg} \mathrm{~m}^{-2} \mathrm{yr}^{-1}$, compared to $+109 \mathrm{~kg} \mathrm{~m}^{-2} \mathrm{yr}^{-1}$ for the period 19812005. This is the consequence of two counteracting evolutions. On one hand, the mean accumulation increases from 291 to $347 \mathrm{~kg} \mathrm{~m}^{-2} \mathrm{yr}^{-1}$, reflecting an increase of the mean total (liquid+solid) precipitation from 316 to $390 \mathrm{~kg} \mathrm{~m}^{-2} \mathrm{yr}^{-1}$, while meltwater runoff increases from 178 to $392 \mathrm{~kg} \mathrm{~m}^{-2} \mathrm{yr}^{-1}$. Mean sublimation/deposition (around $5 \mathrm{~kg} \mathrm{~m}^{-2} \mathrm{yr}^{-1}$ ) is negligible in both simulations. Figure $5 \mathrm{~b}$ displays the surface mass balance for the year 2081-2100. The general pattern, strongly constrained by the geographic situation and the ice sheet surface topography, remains the same as during the latter decades of the 20th century (Fig. 5a). The significant increase of surface melt in the lower parts of the ice sheet more than overcompensates for the precipitation increase which is well visible in the highest parts of Greenland, where melt remains negligible.

\section{Greenland surface mass balance at the end of this century}

G. Krinner and N. Julien

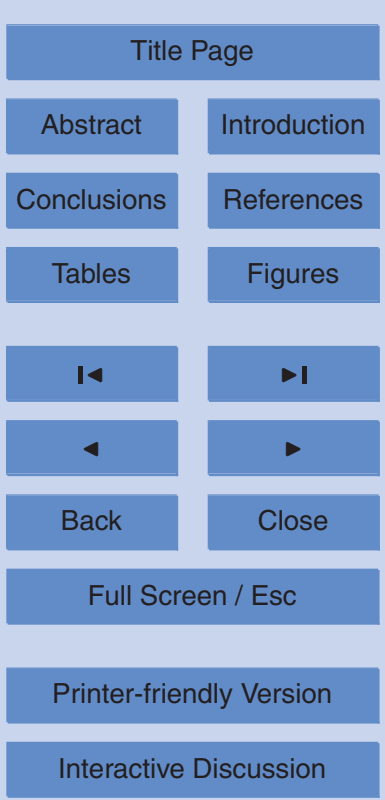


This increase in meltwater production is clearly reflected in the number of days during which surface melt occurs (Fig. 4b). LMDZ4 predicts that under the SRES-A1B greenhouse gas emission scenario melt even occurs in regions above $3000 \mathrm{~m}$ at the end of the 21st century. The melt-free region (here defined as the regions where melt occurs 5 less than once every two years) decreases from $735000 \mathrm{~km}^{2}$ in the period $1981-2005$ to $233000 \mathrm{~km}^{2}$ in the period $2081-2100$.

\section{Discussion}

4.1 Comparison with observations and other simulations of surface mass balance and its components

10 Opposite surface mass balance trends in the interior and in the ice marginal areas are currently observed (Johannessen et al., 2005; Fettweis et al., 2007) and have been predicted by other models (Wild et al., 2003; Kiilsholm et al., 2003). The anthropogenic future climate change simulated by LMDZ4 is therefore consistent with the ongoing observed trends and other model results.

15 As stated before, the simulated mean precipitation over the ice sheet is in good agreement with estimates from glaciological data. The simulated mean sublimation or evaporation over the ice sheet is negligible compared to the mean precipitation. Mote (2003) use a simple surface mass balance model, forced by annual surface melt durations from SSM/I data, to deduce a mean 1988-1999 meltwater production of $20278 \mathrm{~km}^{3} \mathrm{yr}^{-1}$, ranging from 153 to $519 \mathrm{~km}^{3} \mathrm{yr}^{-1}$. Our modelled value for this period is $541 \mathrm{~km}^{3} \mathrm{yr}^{-1}$. This is not necessarily unrealistic, because using this value we obtain an average simulated surface mass balance of $(192 \pm 73) \mathrm{km}^{3} \mathrm{yr}^{-1}$ for 1989 to 1999 , which is not inconsistent with the value of $249 \mathrm{~km}^{3} \mathrm{yr}^{-1}$ estimated by IPCC (2001). Moreover, as we have shown in Sect. 3.1, the simulated melt extent is in good agreement with model-corrected satellite observations by Fettweis et al. (2007).

The Polar MM5 model simulates a mean 1991 to 2000 surface mass balance of

Greenland surface mass balance at the end of this century

G. Krinner and N. Julien

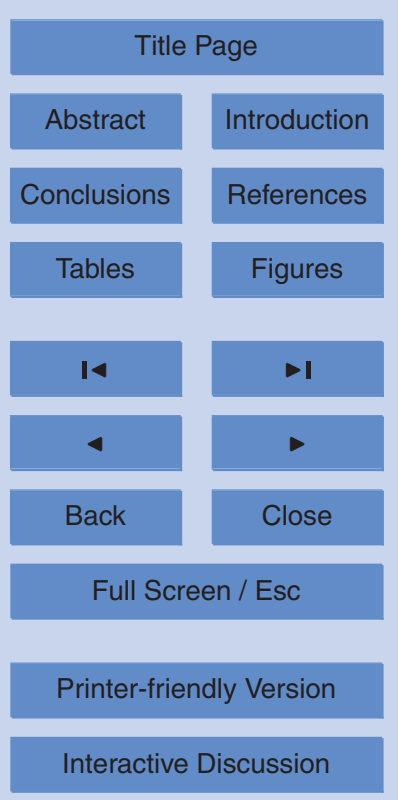


$193 \mathrm{~km}^{3} \mathrm{yr}^{-1}$, with a range of $359 \mathrm{~km}^{3} \mathrm{yr}^{-1}$ (Box et al., 2004). The effect of a parametrization of blowing snow and its sublimation amounts to a volume loss of about $40 \mathrm{~km}^{3} \mathrm{yr}^{-1}$ in MM5. Without this parametrization, the surface mass balance simulated by Polar MM5 would therefore be about $233 \mathrm{~km}^{3} \mathrm{yr}^{-1}$. LMDZ, which does not take into account 5 blowing snow sublimation, yields a mean value of $227 \mathrm{~km}^{3} \mathrm{yr}^{-1}$ for the same period.

Figure 6 displays simulated and observed (van de Wal et al., 2005) surface mass balance values along the Kangerlussuaq transect located at $67^{\circ} \mathrm{N}$ on the western margin of the ice sheet. The measurements were carried out between 1990 and 2003 at 10 sites between 3 and $141 \mathrm{~km}$ from the ice margin, with altitudes varying from $390 \mathrm{~m}$ 10 to $1850 \mathrm{~m}$. Four GCM grid points at $67^{\circ} \mathrm{N}$ lie on this transect (see Fig. 6). This corresponds to a nominal zonal resolution of about $45 \mathrm{~km}$. This is better than the effective resolution of the model dynamics $(60 \mathrm{~km})$ because the zonal distance between adjacent grid points at high latitudes decreases as a consequence of the convergence of the meridian towards the pole. The simulated ablation, which is calculated using the 15 parametrization proposed by Ohmura et al. (1996), is weaker than the measurements indicate, in particular in the central part of the ablation zone at about $800 \mathrm{~m}$ altitude. Ablation is also underestimated when the model-simulated surface melt together with the refreezing parametrization of Pfeffer et al. (1991) is used to calculate ablation instead of the parametrization of Ohmura et al. (1996), which uses the simulated mean 20 summer surface air temperature to diagnose runoff. However, the method by Ohmura et al. (1996) yields a stronger misfit. In both cases the misfit exceeds the interannual variability of about $1 \mathrm{~m}$ typical for this region (Six et al., 2001). The reason for the underestimates of surface melt appears to be that in the model version used in this study, surface albedo over continental ice sheets is fixed and constant (77\%). In reality, 25 surface albedo in this area exhibits a strong annual cycle, with a minimum in summer when bare ice is exposed (van de Wal et al., 2005). Lefebre et al. (2005) have clearly shown that the annual cycle of surface albedo in the ice marginal zone has a significant impact on the simulated ablation. In their model study, a constant surface albedo of $80 \%$ over the ice sheet leads to a $60 \%$ reduction of the simulated surface melt rates.

\section{Greenland surface mass balance at the end of this century}

G. Krinner and N. Julien

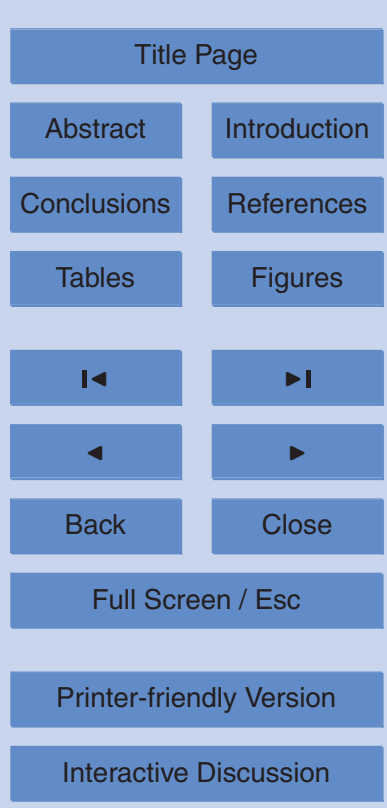


In spite of the inadequate surface albedo in LMDZ4, simulated summer and annual mean values of wind speed, surface air temperature (close to $0^{\circ} \mathrm{C}$ in summer) and incoming short- and longwave radiation at about $1000 \mathrm{~m}$ altitude on the Kangerlussuaq transect (about $37 \mathrm{~km}$ from the ice sheet margin in reality) are in fairly good agreement 5 with the measured values given by van de Wal et al. (2005). The simple formulation of ice sheet surface albedo (a prescribed, fixed value of $77 \%$ ) has been deliberately chosen in spite of the existence of a more elaborate parametrization in LMDZ4 (Krinner et al., 2006), which takes into account solar zenith angle, snow grain size, dust and soot content in snow, and snow height, because the version of LMDZ4 used here is the 10 version used in the IPSL-CM4 coupled IPCC model runs from which the sea-surface conditions used in this study were deduced.

\subsection{Analysis of the simulated future precipitation change}

The overall precipitation increase over Greenland ( $+23 \%$, from 316 to $390 \mathrm{~kg} \mathrm{~m}^{-2} \mathrm{yr}^{-1}$ ) is consistent with a general tendency to precipitation increase in polar regions during 15 climate warming, which is a common feature in climate models (e.g., Kiilsholm et al., 2003; Gregory and Huybrechts, 2006; Krinner et al., 2007). However, the simulated precipitation change is not spatially uniform over the ice sheet. Figure 7 a displays the change in annual mean precipitation between the two periods considered in this work. Precipitation regionally increases by up to $70 \%$, but decreases by up to $15 \%$ near the 20 south-western margin of the ice sheet.

For a range of coupled climate models used in the most recent IPCC climate change assessment, Gregory and Huybrechts (2006) calculated the sensitivity of the simulated relative ice-sheet mean precipitation change $\Delta P / P$ to the ice-sheet mean surface air temperature change $\Delta T: s=(\Delta P / P) / \Delta T$. They obtain a mean value of $(4.7 \pm 1.0) \% \mathrm{~K}^{-1}$. 25 Our model indicates a somewhat higher sensitivity of $6.2 \% \mathrm{~K}^{-1}$. This seems to be linked to the higher spatial resolution used in this study than in the AOGCM simulations analysed by Gregory and Huybrechts (2006). Krinner et al. (2007) showed that the high resolution models used in the recent IPCC exercise tend to produce stronger

Greenland surface mass balance at the end of this century

G. Krinner and N. Julien

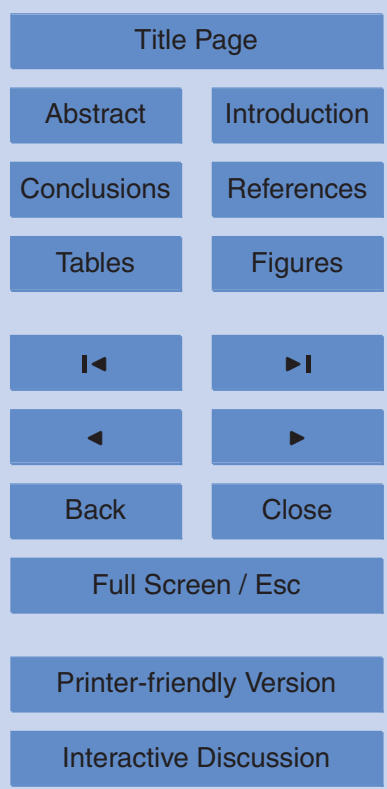


precipitation changes than the lower-resolution models, and they observe that, similarly, their high-resolution simulations over Antarctica with LMDZ also produce stronger precipitation changes than the IPSL-CM4 coupled climate model, which runs at lower resolution; LMDZ is the atmospheric component of IPSL-CM4. Uotila et al. (2007) 5 also noticed that among the models used for the most recent IPCC climate change projections, the MIROC3.2(hires) AOGCM, which has the highest resolution of the participating models, yields the strongest P-E change over Antarctica. Krinner et al. (2007) showed that in Antarctica, this dependency of the simulated precipitation change on the horizontal resolution is due to a better representation of the coastal precipitation, which 10 is influenced by steep topographical gradients. In the case of the Greenland simulations presented here, the high ice-sheet mean precipitation sensitivity to temperature changes is primarily caused by a strong absolute precipitation increase along the western margin of the ice sheet (Fig. $7 \mathrm{~b}$ ), coupled to a relatively weak temperature increase in that region (Fig. 8). As for Antarctica, therefore, the better resolution of coastal pro15 cesses leads to a modified assessment of ice-sheet wide precipitation changes. It is noteworthy that a recent analysis of satellite observations over the last two decades suggests a global precipitation sensitivity of about $6 \% \mathrm{~K}^{-1}$ (Wentz et al., 2007), which is significantly higher than climate change experiments with coupled models suggest (Allen and Ingram, 2002). In the light of our results, one might speculate that future assessments using higher-resolution coupled climate models could better represent the observed precipitation sensitivity.

This precipitation decrease in the South-East is the consequence of a simulated shift towards a more positive mean state of the NAO during at the end of the 21st century. Using a method based on equivalent isobaric geopotential height to retrieve precipitation over Greenland, Bromwich et al. (1999) have shown that during winter there is a strong correlation $(r=-0.80)$ between the NAO index and the mean precipitation over southern Greenland, where most of the simulated precipitation indeed occurs during that season. Figure 9 displays the simulated winter (DJF) sea-level pressure change from 1981-2005 to 2081-2100, from which the increased pressure difference between

Greenland surface mass balance at the end of this century

G. Krinner and N. Julien

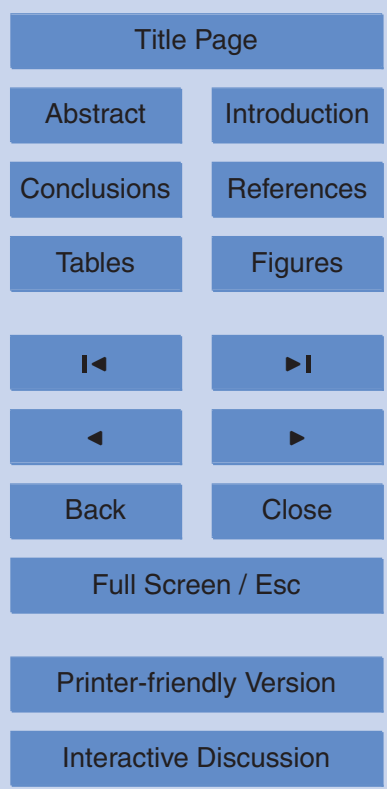

EGU 
the Azores and Iceland, signifying a more positive mean NAO phase, is obvious. Displaying a general pressure decrease in high latitudes and a pressure increase further south, this figure also shows a more positive mean state of the more general northern hemisphere annular mode ("Arctic Oscillation"). This is a common trend in climate 5 change simulations (Fyfe et al., 1999). In part, the precipitation decrease in south-east Greenland might also be linked to the very moderate warming (and even a localized cooling) at the surface of the adjacent seas (Fig. 8), which means that the oceanic moisture source off south-eastern Greenland will probably not increase in strength over the 21st century.

In terms of ice sheet surface mass balance, precipitation increase is less efficient if the additional precipitation falls as rain. Figure 10 displays the fraction of total precipitation that falls as rain (denoted $F_{R}$ in the following) in the two simulations and the simulated change over the 21 st century. For obvious reasons rain occurs preferentially in the low-lying ice marginal regions. This signal is modulated by the precipitation sea15 sonality: $F_{R}$ is fairly high in the south-west of Greenland and fairly low along the southeastern coast because the precipitation maximum occurs in summer in the south-west and in winter in the south-east (Fig. 11a). The situation in southern Greenland is not so clear at the end of the 21st century (Fig. 11b). Precipitation increase along the south-western ice sheet margin is strong in winter, such that $F_{R}$ does not increase as strongly as one might expect (Fig. 10c). In contrast, $F_{R}$ strongly increases along the north-western margin of the ice sheet, where precipitation remains maximum during the summer months (Fig. 11b).

\subsection{Potential large-scale impacts of the simulated surface mass balance changes}

Although the surface mass balance is only one part of the total ice sheet mass balance 25 - the total mass balance is the sum of surface mass balance, basal melt and iceberg discharge -, it is of interest to discuss the potential large-scale impacts of the projected surface mass balance changes during the next century. These large-scale impacts are of two kinds: First, increased runoff from the ice sheet could influence the meridional

Greenland surface mass balance at the end of this century

G. Krinner and N. Julien

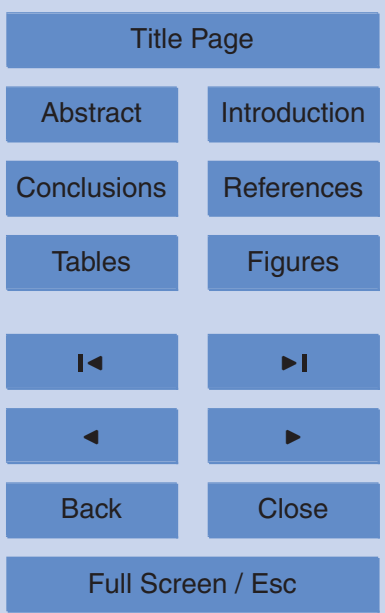

Printer-friendly Version

Interactive Discussion 
overturning circulation in the North Atlantic (Stommel, 1961; Rahmstorf, 1995). Second, the mass balance of the Greenland ice sheet is one of the contributions to future sea-level changes.

Figure 12 displays the simulated ice sheet runoff (that is, the sum of the part of liq5 uid precipitation that immediately runs off and the part of surface meltwater that does not refreeze) for the two periods considered here. Similar to Arzel et al. (2007), the ice sheet runoff is given for different sectors of the surrounding seas (Arctic Ocean, Labrador Sea, Greenland-Iceland-Norway Seas north of the Greenland-Iceland sill, and Greenland-Iceland-Norway Seas south of the Greenland-Iceland sill) as well as 10 for the whole ice sheet. During both periods, the surface freshwater flux towards the Labrador Sea amounts to about $50 \%$ of the total surface freshwater flux. Interannual variations of the total freshwater flux as well as its trends are dominated by this component. During the period 1981 to 2005, the total freshwater flux exhibits a slight positive trend, but the interannual variations are, interestingly, not well correlated to those of the cumulated melt area (Fig. 3). During the final decades of the 21st century, the total freshwater flux has a clear increasing trend. The mean total freshwater flux increases from $0.0195 \mathrm{~Sv}$ (1981 to 2005 ) to $0.0370 \mathrm{~Sv}$ (2081 to 2100$)$. This increase of $0.0175 \mathrm{~Sv}$ is more than the freshwater flux increase computed by Fichefet et al. (2003) using an atmosphere-ocean GCM coupled to an ice sheet model (compared to climate change simulations not coupled to the dynamic ice sheet model). In the study by Fichefet et al. (2003), this freshwater flux increase led to a strong and abrupt weakening of the North Atlantic thermohaline circulation (THC) at the end of the 21st century. However, "hosing" experiments carried out with a number of coupled ocean-atmosphere circulation models (Stouffer et al., 2006) suggest that, at least under present climate conditions,

25 an additional freshwater flux of $0.1 \mathrm{~Sv}$ into the northern North Atlantic only leads to a $\approx 30 \%$ reduction of the THC intensity after 100 years. The additional freshwater flux from Greenland suggested by the present study will thus probably not lead to a strong reduction of the THC. However, considering that LMDZ4 suggests that about $50 \%$ of the simulated additional freshwater flux from Greenland will flow into the relatively small

Greenland surface mass balance at the end of this century

G. Krinner and N. Julien

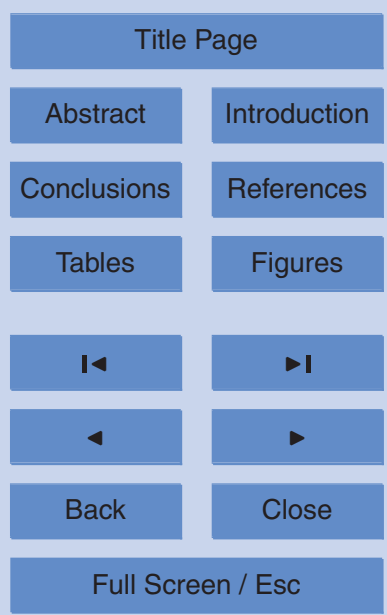

Printer-friendly Version

Interactive Discussion 
Labrador Sea (see Fig. 11), a localized interruption of oceanic convection in this area might appear somewhat less improbable.

The integrated surface mass balance change from 1981-2005 (mean surface mass balance: $109 \mathrm{~kg} \mathrm{~m}^{-2} \mathrm{yr}^{-1}$ ) to $2081-2100$ (mean value: $-51 \mathrm{~kg} \mathrm{~m}^{-2} \mathrm{yr}^{-1}$ ) corresponds 5 to an eustatic sea-level change of $0.8 \mathrm{~mm} / \mathrm{yr}$. Supposing a linear surface mass balance change over the next century (that is, an average induced sea-level change of $0.4 \mathrm{~mm}$ /year), this would lead to a sea-level change of $0.04 \mathrm{~m}$ in 100 years, between 8 and $20 \%$ of the sea-level change (excluding possible future rapid dynamical changes in ice flow) projected by the IPCC (2007) under the SRES-A1B greenhouse gas emission 10 scenario. In the absence of a preindustrial "equilibrium" simulation, the contribution of the present-day simulated surface mass balance to the observed sea-level rise of about $3 \mathrm{~mm} / \mathrm{yr}$ since 1993 (Cazenave et al., 2003) cannot be estimated. Figure 13 shows that there is a slight trend to decreasing surface mass balances in the presentday simulation, suggesting a presently increasing contribution of the Greenland surface mass balance to sea-level changes, in agreement with observations of ongoing intensification of surface melt (e.g., Fettweis et al., 2007). It is noteworthy that Fig. 13 also shows that the interannual variability of the simulated surface mass balance is quite high $\left(\sigma=43 \mathrm{~kg} \mathrm{~m}^{-2} \mathrm{yr}^{-1}\right)$, but lower than in the model study by Box et al. (2004) who found an interannual variability of $\pm 102 \mathrm{~kg} \mathrm{~m}^{-2} \mathrm{yr}^{-1}$.

\section{Conclusions}

Under the SRES-A1B greenhouse gas emission scenario, the LMDZ4 AGCM suggests a significant increase of meltwater production over the Greenland ice sheet over the next century, leading to a strong intensification of fresh water influx into the Labrador Sea. Precipitation changes over the 21 st century are a mixed signal of local and regional effects. The precipitation increase over the central ice sheet appears to be linked to the simulated warming, while the drying near the south-eastern coast is linked to a shift towards a more positive mean NAO phase. Our simulations suggest a fairly high

Greenland surface mass balance at the end of this century

G. Krinner and N. Julien

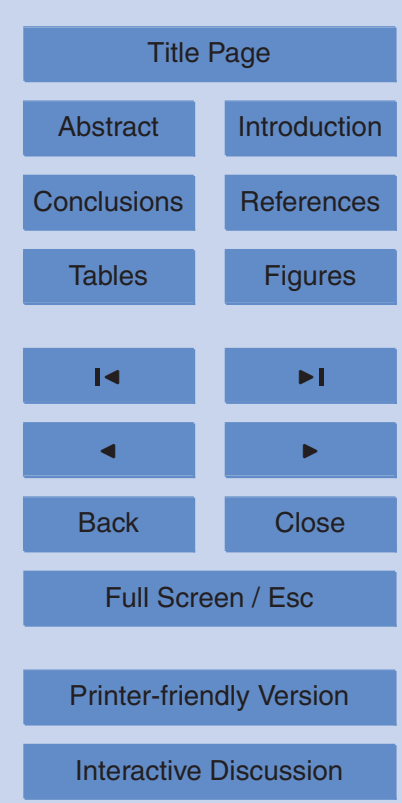

EGU 
sensitivity of precipitation to temperature changes, $s=6.2 \% \mathrm{~K}^{-1}$, compared to a mean value of $(4.7 \pm 1.0) \% \mathrm{~K}^{-1}$ obtained by Gregory and Huybrechts (2006). Our results suggest that this is due to the better representation of coastal precipitation at higher spatial resolution.

$5 \quad$ Altogether, the diagnosed integrated surface mass balance change from 1981-2005 to 2081-2100 corresponds to an eustatic sea-level rise of $0.8 \mathrm{~mm} / \mathrm{yr}$, because surface melt increase largely outweighs the precipitation increase in the interior. Although the method of diagnosing surface meltwater production used here (Ohmura et al., 1999) is based on sound considerations, future work will aim on developing methods of physical downscaling of the ablation terms near the ice sheet margin. Also, in these future studies, surface albedo on the ice sheet will be calculated using the parametrization of Krinner et al. (2006), which would certainly lead to higher simulated runoff from the ice sheet. We cannot exclude that these refined studies could yield significantly different estimates of the future surface mass balance changes of the Greenland ice sheet.

15 Acknowledgements. This work was financed by the European Commission under the FP6 integrated project ENSEMBLES.

\section{References}

Allen, M. and Ingram, W.: Constraints on future changes in climate and the hydrologic cycle, Nature, 419, 224-232, 2002. 362

Alley, R., Clark, P., Huybrechts, P., and Joughin, I.: Ice-Sheet and Sea-Level Changes, Science, 310, 456-460, 2005. 352

Arzel, O., Fichefet, T., Goosse, H., and Dufresne, J.-L.: Causes and impacts of changes in the Arctic freshwater budget during the 20th and 21st centuries in an AOGCM, Clim. Dyn., in press, doi:10.1007/s00382-007-0258-5, 2007. 364

Box, J., Bromwich, D., and Bai, L.: Greenland ice sheet surface mass balance 1991-2000: Application of Polar MM5 mesoscale model and in situ data, J. Geophys. Res, 109, D08207, doi:10.1029/2003JD004292, 2004. 356, 358, 360, 365

\section{Greenland surface mass balance at the end of this century}

G. Krinner and N. Julien

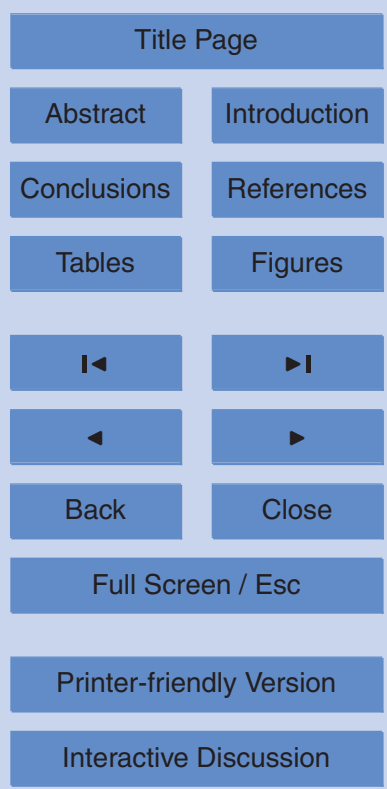


Bromwich, D., Chen, Q., Li, Y., and Cullather, R.: Precipitation over Greenland and Its Relation to the North Atlantic Oscillation, J. Geophys. Res.-Atmos., 104, 22-103, 1999. 358, 362

Cazenave, A.: How Fast Are the Ice Sheets Melting?, Science, 314, 1250-1252, 2006. 352

Cazenave, A., Cabanes, C., Dominh, K., Gennero, M., and Le Provost, C.: Present-Day Sea Level Change: Observations and Causes, Space Sci. Rev., 108, 131-144, 2003. 365

Chen, J., Wilson, C., and Tapley, B.: Satellite Gravity Measurements Confirm Accelerated Melting of Greenland Ice Sheet, Science, 313, 1958-1960, 2006. 352

De Angelis, H. and Skvarca, P.: Glacier Surge After Ice Shelf Collapse, Science, 299, 15601562, 2003. 353

10 Dethloff, K., Schwager, M., Christensen, J., Kiilsholm, S., Rinke, A., Dorn, W., JungRothenhäusler, F., Fischer, H., Kipfstuhl, S., and Miller, H.: Recent Greenland Accumulation Estimated from Regional Climate Model Simulations and Ice Core Analysis, Journal of Climate, 15, 2821-2832, 2002. 358

Dowdeswell, J.: The Greenland Ice Sheet and Global Sea-Level Rise, Science, 311, 963-964, 2006. 353

Ekholm, S.: A full coverage, high-resolution, topographic model of Greenland computed from a variety of digital elevation data, J. Geophys. Res, 101, 21 961-21 972 , 1996. 355

Fettweis, X., Gallée, H., Lefebre, F., and van Ypersele, J.: Greenland surface mass balance simulated by a regional climate model and comparison with satellite-derived data in 19901991, Clim. Dyn., 24, 623-640, 2005. 358

Fettweis, X., van Ypersele, J., Gallée, H., Lefebre, F., and Lefebvre, W.: The 1979-2005 Greenland ice sheet melt extent from passive microwave data using an improved version of the melt retrieval XPGR algorithm, Geophys. Res. Lett., 34, L05502, doi:10.1029/2006GL028787, 2007. 353, 357, 359, 365, 374

Fichefet, T., Poncin, C., Goosse, H., Huybrechts, P., Janssens, I., and Le Treut, H.: Implications of changes in freshwater flux from the Greenland ice sheet for the climate of the 21st century, Geophys. Res. Lett, 30(17), 1911, doi:10.1029/2003GL017826, 2003364

Forster, P. and Taylor, K.: Climate Forcings and Climate Sensitivities Diagnosed from Coupled Climate Model Integrations, J. Climate, 19, 6181-6194, 2006. 355

30 Fyfe, J., Boer, G., and Flato, G.: Arctic and Antarctic oscillations and their projected changes under global warming, Geophys. Res. Lett., 26, 1601-1604, 1999. 363

Gregory, J. and Huybrechts, P.: Ice-sheet contributions to future sea-level change, Philosophical Transactions of the Royal Society A: Mathematical, Phys. Eng. Sci., 364, 1709-1731,

Greenland surface mass balance at the end of this century

G. Krinner and N. Julien

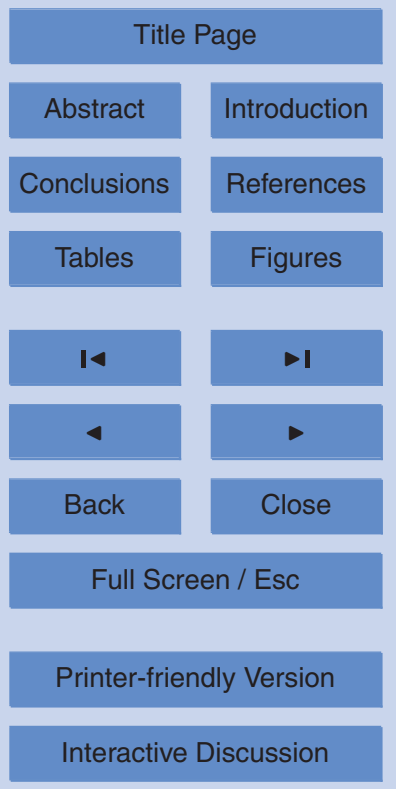

EGU 
2006. $354,361,366$

Gregory, J., Huybrechts, P., and Raper, S.: Threatened loss of the Greenland ice-sheet, Nature, 428, 257-267, 2004. 354

Hourdin, F., Musat, I., Bony, S., Braconnot, P., Codron, F., Dufresne, J., Fairhead, L., Filiberti, M., Friedlingstein, P., Grandpeix, J., et al.. The LMDZ4 general circulation model. climate peformance and sensitivity to parametrized physics with emp Clim. Dyn., 27, 787-813, 2006. 354

IPCC: Climate Change 2001: The Scientific Basis. Contribution of Working Group I to the Third Assessment Report of the Intergovernmental Panel on Climate Change, 2001. 353, 357, 359

IPCC: Climate Change 2007: The Physical Science Basis-Summary for Policymakers, IPCC WGI 4th Assessment Report, Intergovernmental Panel on Climate Change, Geneva, 1-21, 2007. 353, 365

Johannessen, O., Khvorostovsky, K., Miles, M., and Bobylev, L.: Recent Ice-Sheet Growth in the Interior of Greenland, Science, 310, 1013-1016, 2005. 352, 359

Kiilsholm, S., Christensen, J., Dethloff, K., and Rinke, A.: Net accumulation of the Greenland ice sheet: High resolution modeling of climate changes, Geophys. Res. Lett, 30, 1485, doi:10.1029/2002GL015742, 2003. 353, 359, 361

Krabill, W., Frederick, E., Manizade, S., Martin, C., Sonntag, J., Swift, R., Thomas, R., Wright, W., and Yungel, J.: Rapid Thinning of Parts of the Southern Greenland Ice Sheet, Science, 283, 1522-1524, 1999. 352

Krabill, W., Hanna, E., Huybrechts, P., Abdalati, W., Cappelen, J., Csatho, B., Frederick, E., Manizade, S., Martin, C., Sonntag, J., et al.: Greenland Ice Sheet: Increased coastal thinning, Geophys. Res. Lett, 31, L24402, doi:10.1029/2004GL021533, 2004. 352, 353

Krinner, G. and Genthon, C.: Altitude dependence of the ice sheet surface climate, Geophys. Res. Lett., 26, 2227-2230, 1999. 355

Krinner, G., Genthon, C., Li, Z., and Le Van, P.: Studies of the Antarctic climate with a stretchedgrid general circulation model, J. Geophys. Res, 102, 731-13, 1997. 355

Krinner, G., Boucher, O., and Balkanski, Y.: Ice-free glacial northern Asia due to dust deposition on snow, Clim. Dyn., 27, 613-625, 2006. 361, 366

Krinner, G., Magand, O., Simmonds, I., Genthon, C., and Dufresne, J.: Simulated Antarctic precipitation and surface mass balance at the end of the twentieth and twenty-first centuries, Clim. Dyn., 28, 215-230, 2007. 357, 361, 376

\section{Greenland surface mass balance at the end of this century}

G. Krinner and N. Julien

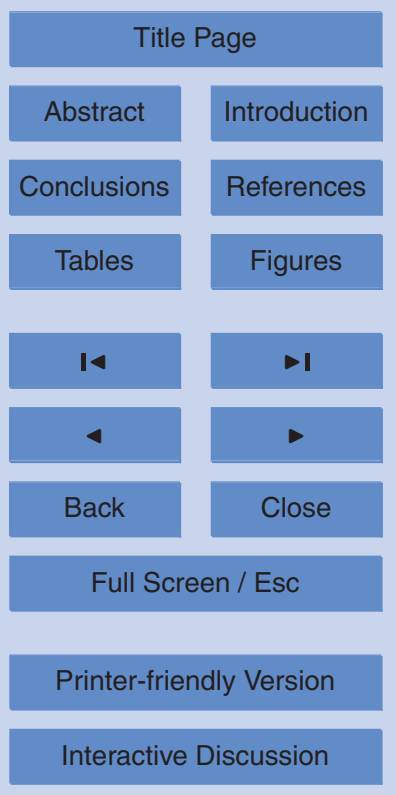


Krinner, G., Guicherd, B., Ox, K., Genthon, C., and Magand, O.: Influence of oceanic boundary conditions in simulations of Antarctic climate and surface mass balance change during the coming century, J. Climate, accepted, 2007. 355, 361, 362

Lefebre, F., Fettweis, X., Gallée, H., Van Ypersele, J., Marbaix, P., Greuell, W., and Calanca, P.:

5 Evaluation of a high-resolution regional climate simulation over Greenland, Clim. Dyn., 25, 99-116, 2005. 360

Liston, G. and Winther, J.: Antarctic Surface and Subsurface Snow and Ice Melt Fluxes, J. Climate, 18, 1469-1481, 2005. 355

Luthcke, S., Zwally, H., Abdalati, W., Rowlands, D., Ray, R., Nerem, R., Lemoine, F., McCarthy, J., and Chinn, D.: Recent Greenland Ice Mass Loss by Drainage System from Satellite Gravity Observations, Science, 314, 1286-1289, 2006. 352

Marti, O., Braconnot, P., Bellier, J., Benshila, R., Bony, S., Brockmann, P., Cadule, P., Caubel, A., Denvil, S., Dufresne, J., et al.: The new IPSL climate system model: IPSL-CM4, Tech. rep., Institut Pierre Simon Laplace, Paris, 2005. 355

Mote, T.: Estimation of runoff rates, mass balance, and elevation changes on the Greenland ice sheet from passive microwave observations, J. Geophys. Res, 108, 4056, doi:10.1029/2001JD002032, 2003. 359

Oerlemans, J., Dahl-Jensen, D., et al.: Ice Sheets and Sea Level, Science, 313, 1043c, 2006. 353

Ohmura, A. and Reeh, N.: New precipitation and accumulation maps for Greenland, J. Glaciol., 37, 140-148, 1991. 357, 358

Ohmura, A., Wild, M., and Bengtsson, L.: A Possible Change in Mass Balance of Greenland and Antarctic Ice Sheets in the Coming Century, J. Climate, 9, 2124-2135, 1996. 353, 355, 356, 357, 358, 360, 376

Ohmura, A., Calanca, P., Wild, M., and Anklin, M.: Precipitation, accumulation and mass balance of the Greenland Ice Sheet, Zeitschrift für Gletscherkunde und Glazialgeologie, 35, 1-20, 1999. 357, 358, 366

Overpeck, J., Otto-Bliesner, B., Miller, G., Muhs, D., Alley, R., and Kiehl, J.: Paleoclimatic Evidence for Future Ice-Sheet Instability and Rapid Sea-Level Rise, Science, 311, 17471750, 2006. 353

Pfeffer, W., Meier, M., and Illangasekare, T.: Retention of Greenland runoff by refreezing: implications for projected future sea level change, J. Geophys. Res., 96, 22 117-22 124, 1991. 360, 376

Greenland surface mass balance at the end of this century

G. Krinner and N. Julien

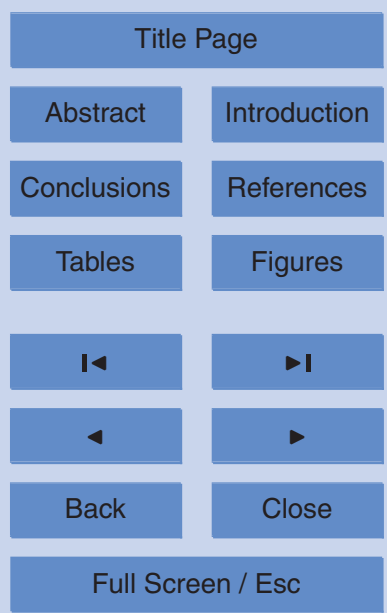

Printer-friendly Version

Interactive Discussion 
Rahmstorf, S.: Bifurcations of the Atlantic thermohaline circulation in response to changes in the hydrological cycle, Nature, 378, 145-149, 1995. 364

Rahmstorf, S.: A Semi-Empirical Approach to Projecting Future Sea-Level Rise, Science, 315, 368, 2007. 353

5 Rignot, E. and Kanagaratnam, P.: Changes in the Velocity Structure of the Greenland Ice Sheet, Science, 311, 986-990, 2006. 352

Six, D., Letréguilly, A., and Reynaud, L.: Greenland ice-sheet mass-balance distribution: a variance analysis of existing field data, J. Glaciol., 47, 441-451, 2001. 360

Steffen, K.: Greenland Climate Network, 2005. 356

10 Stommel, H.: Thermohaline convection with two stable regimes of flow, Tellus, 13, 224-230, 1961. 364

Stouffer, R., Seidov, D., and Haupt, B.: Climate Response to External Sources of Freshwater: North Atlantic versus the Southern Ocean, J. Climate, 20, 436-448, 2006. 364

Uotila, P., Lynch, A., Cassano, J., and Cullather, R.: Changes in Antarctic net precipitation in the 21st century based on Intergovernmental Panel on Climate Change (IPCC) model scenarios, J. Geophys. Res., 112, D10107, doi:10.1029/2006JD007482, 2007. 362

van de Wal, R., Greuell, W., van den Broeke, M., Tijm-Reijmer, C., and Oerlemans, J.: Mass Balance observations and automatic weatherstation data along a transect near Kangerlussuaq, West Greenland, Ann. Glaciol, 42, 311-316, 2005. 360, 361, 376 tica, Science, 311, 1754-1756, 2006. 352

Wentz, F., Ricciardulli, L., Hilburn, K., and Mears, C.: How Much More Rain Will Global Warming Bring?, Science, 317, 233, 2007. 362

Wild, M., Calanca, P., Scherrer, S., and Ohmura, A.: Effects of polar ice sheets on global sea level in high-resolution greenhouse scenarios, J. Geophys. Res, 108, 2003. 353, 359

Zwally, H., Giovinetto, M., Li, J., Cornejo, H., Beckley, M., Brenner, A., Saba, J., and Yi, D.: Mass changes of the Greenland and Antarctic ice sheets and shelves and contributions to sea-level rise: 1992-2002, J. Glaciol., 51, 509-527, 2005. 352, 353

\section{Greenland surface mass balance at the end of this century}

G. Krinner and N. Julien

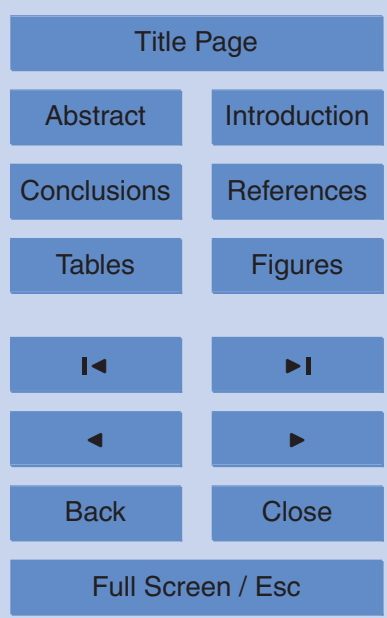

Printer-friendly Version

Interactive Discussion 


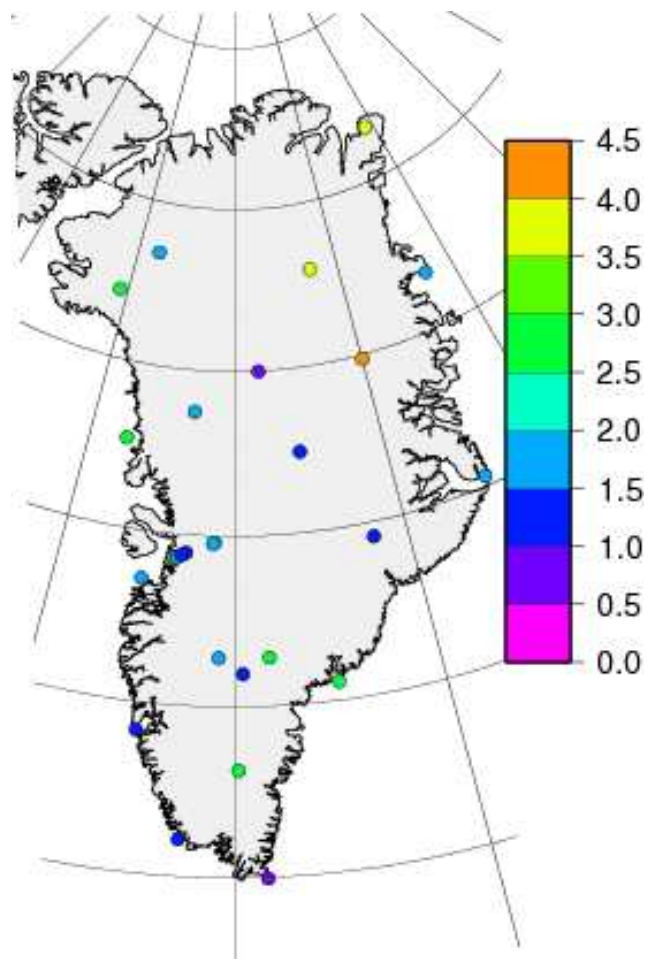

$1,351-383,2007$

\section{Greenland surface mass balance at the end of this century}

G. Krinner and N. Julien

Title Page

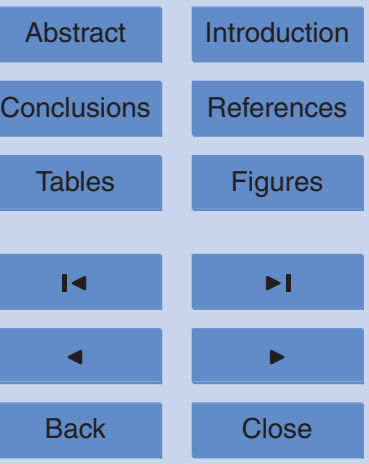

Full Screen / Esc

Fig. 1. Simulated surface air temperature compared to AWS and manned station measurements. Mean absolute monthly mean error (see text) in ${ }^{\circ} \mathrm{C}$ for the reference simulation $1981-$ 2005.

Printer-friendly Version

Interactive Discussion 


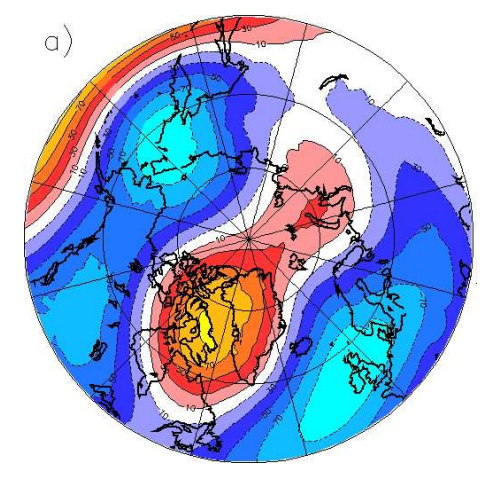

\section{Greenland surface mass balance at the end of this century}

G. Krinner and N. Julien
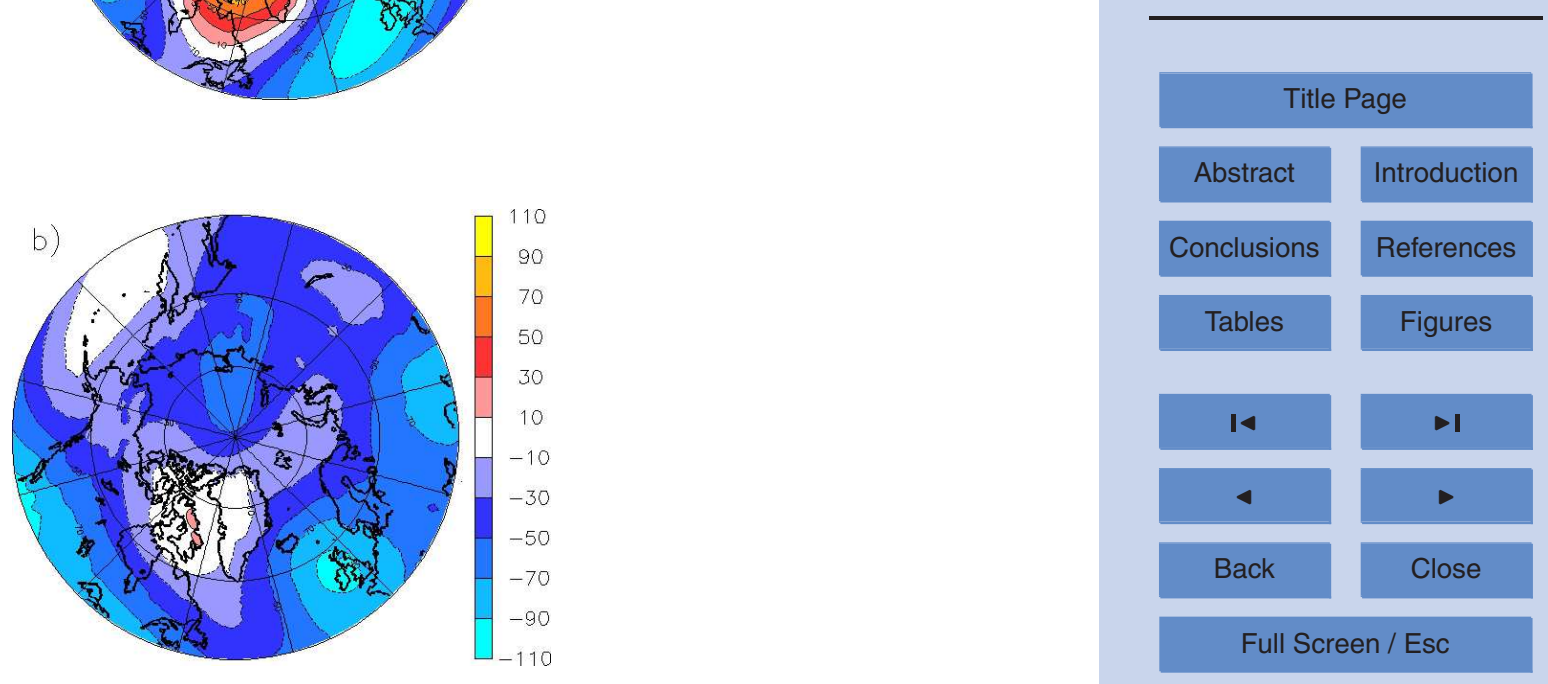

Fig. 2. Difference between simulated and analysed (NCEP) $500 \mathrm{hPa}$ height (in $\mathrm{m}$ ) for the period 1981-2005. (a) Winter (DJF); (b) Summer (JJA). 


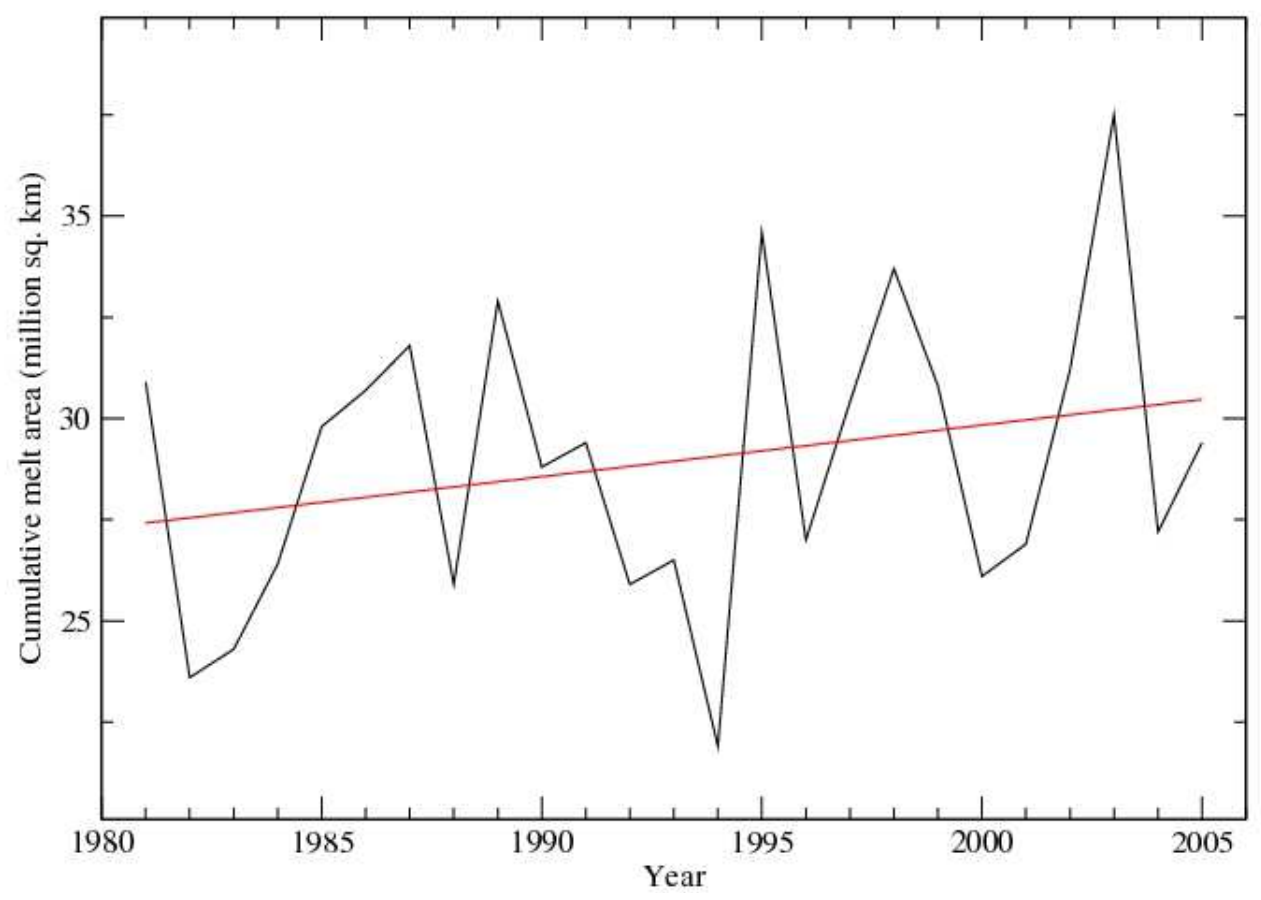

Fig. 3. Cumulative melt area (in $10^{6} \mathrm{~km}^{2}$ ) as simulated by LMDZ4 for the period 1981-2005.

\section{Greenland surface mass balance at the end of this century}

G. Krinner and N. Julien

Title Page

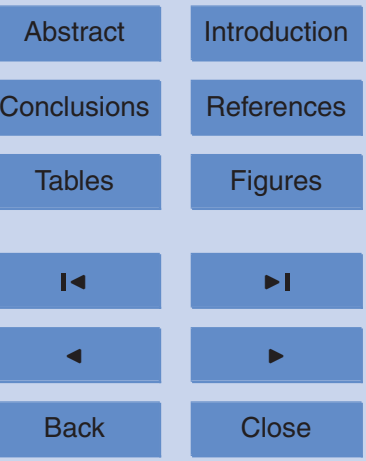

Full Screen / Esc

Printer-friendly Version

Interactive Discussion 

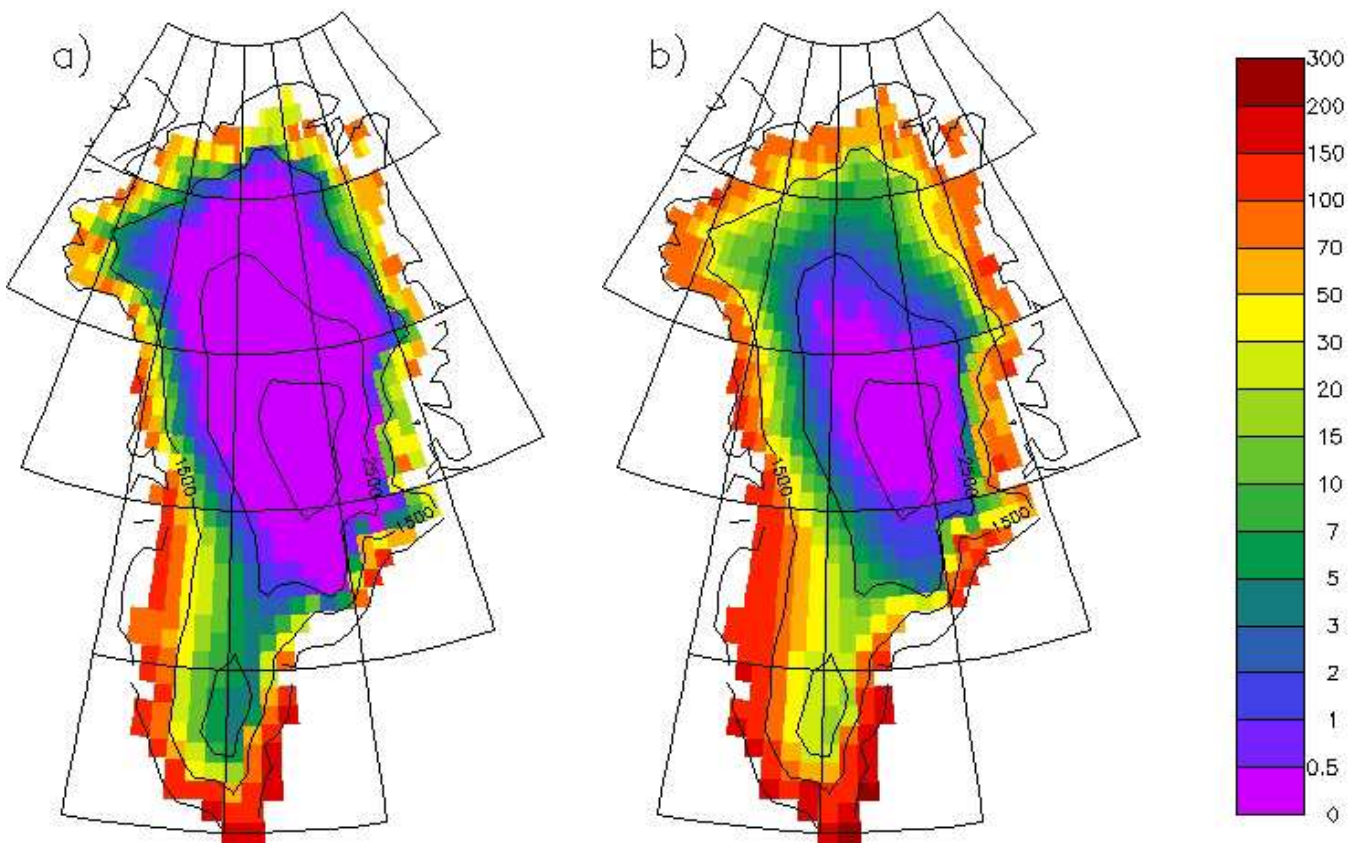

\section{Greenland surface mass balance at the end of this century}

G. Krinner and N. Julien

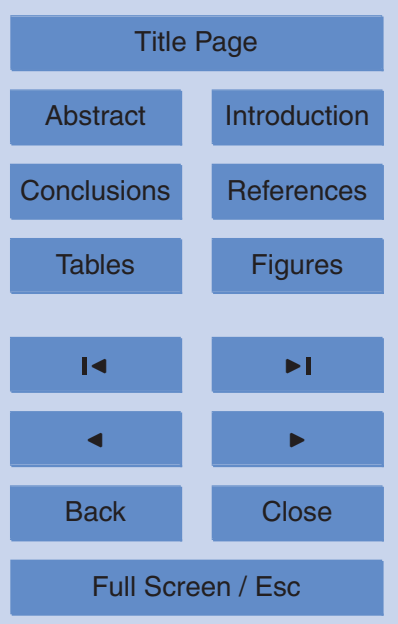

Fig. 4. Simulated number of days with snow melt per year. (a) 1981-2005. (b) 2081-2100. Surface height contours are given at 1500,2500 and $3000 \mathrm{~m}$ to facilitate the comparison with Fig. 3 of Fettweis et al. (2007).

Printer-friendly Version

Interactive Discussion 

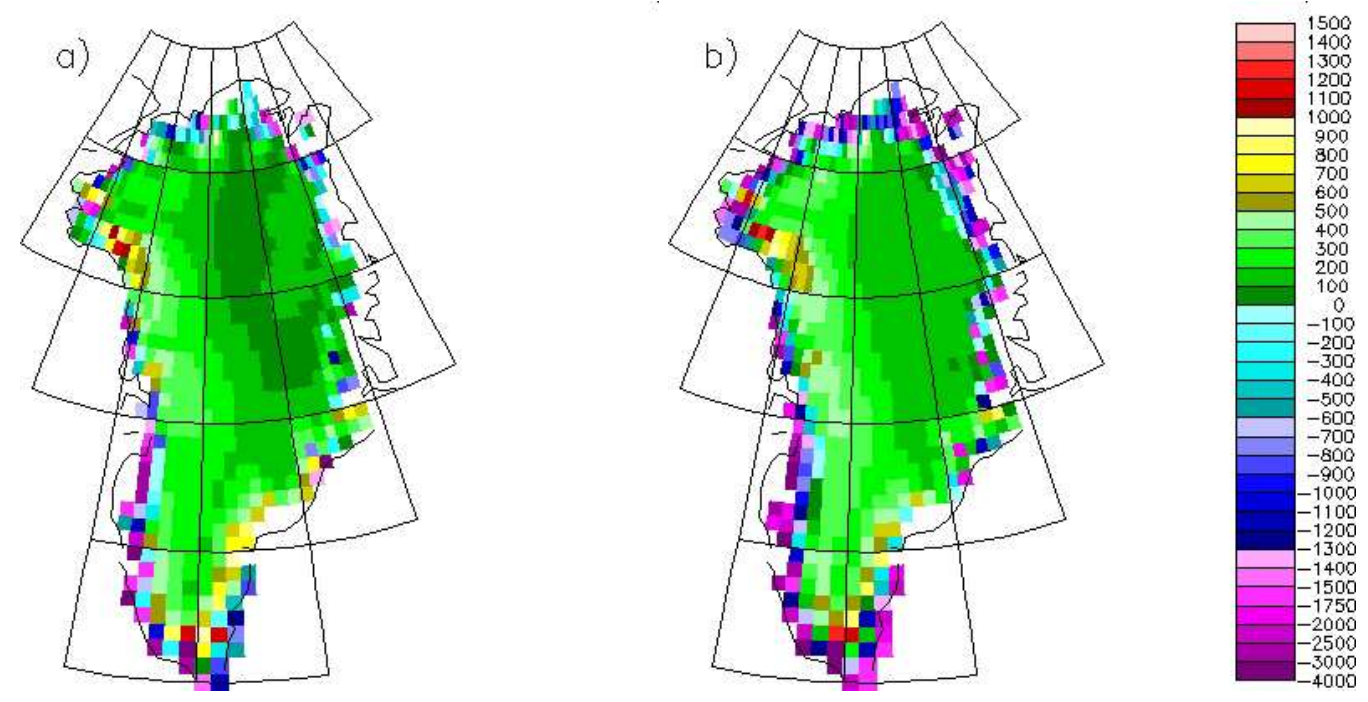

\section{Greenland surface mass balance at the end of this century}

G. Krinner and N. Julien

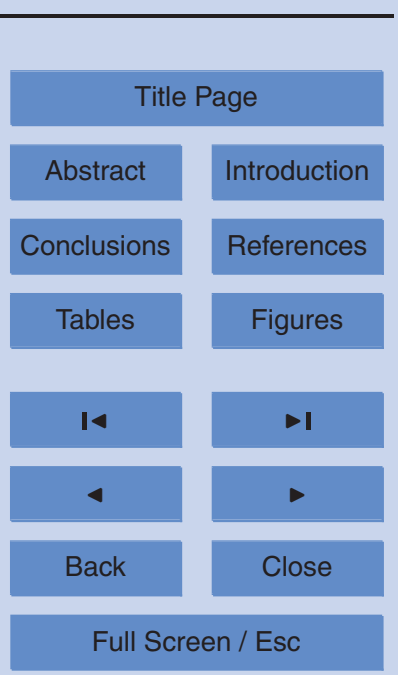

Fig. 5. Simulated surface mass balance (in $\mathrm{kg} / \mathrm{m}^{2} / \mathrm{yr}$ ) for (a) 1981-2000 and (b) 2081-2100. 


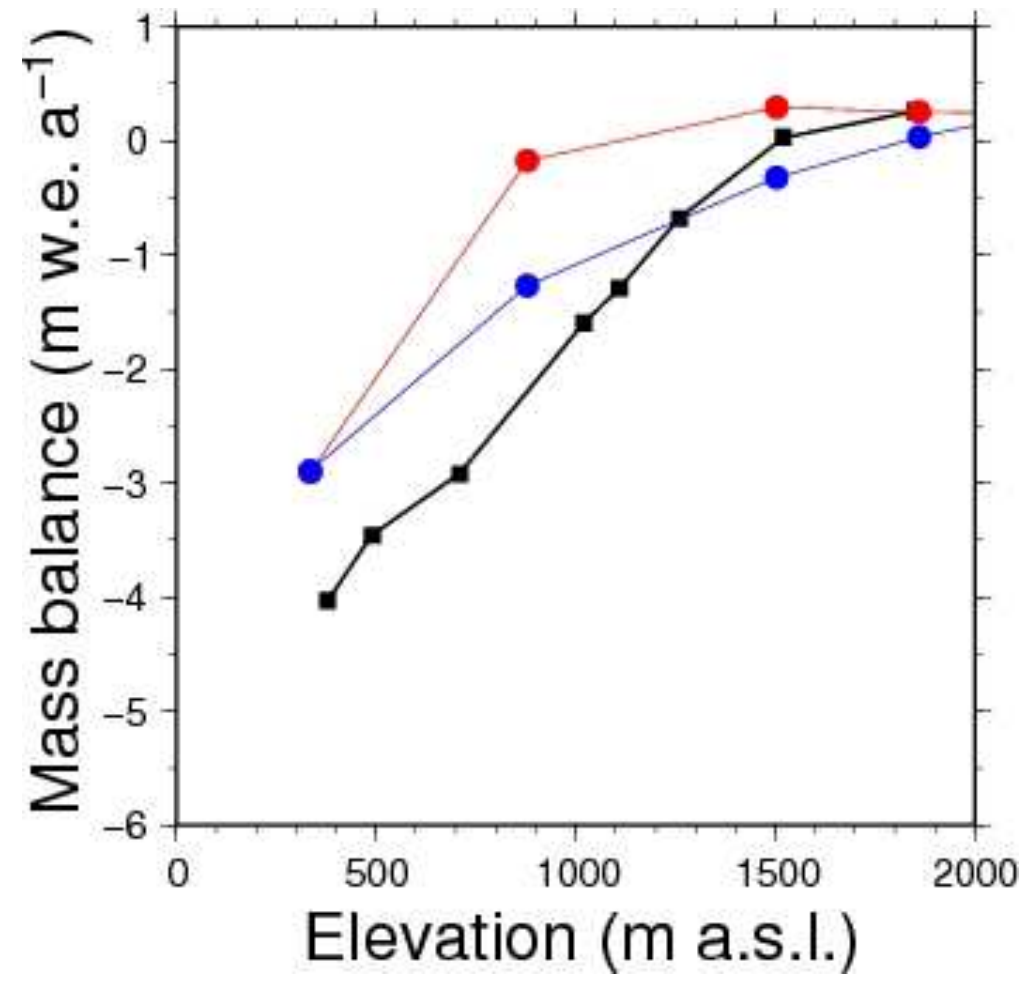

Fig. 6. Observed (squares; van de Wal et al., 2005) and simulated (coloured circles) surface mass balance (in $\mathrm{kg} \mathrm{m}^{-2} \mathrm{yr}^{-1}$ ) for the years 1990 to 2003 along the Kangerlussuaq transect at $67^{\circ} \mathrm{N}$. Red circles: Ablation calculated using the parametrization of Ohmura et al. (1996); Blue circles: Ablation calculated as in Krinner et al. (2007), i.e. using the meltwater refreezing parametrization of Pfeffer et al. (1991).

\section{TCD}

1, 351-383, 2007

\section{Greenland surface} mass balance at the end of this century

G. Krinner and N. Julien

Title Page

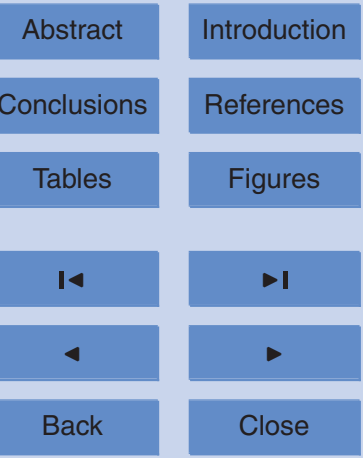

Full Screen / Esc

Printer-friendly Version

Interactive Discussion 

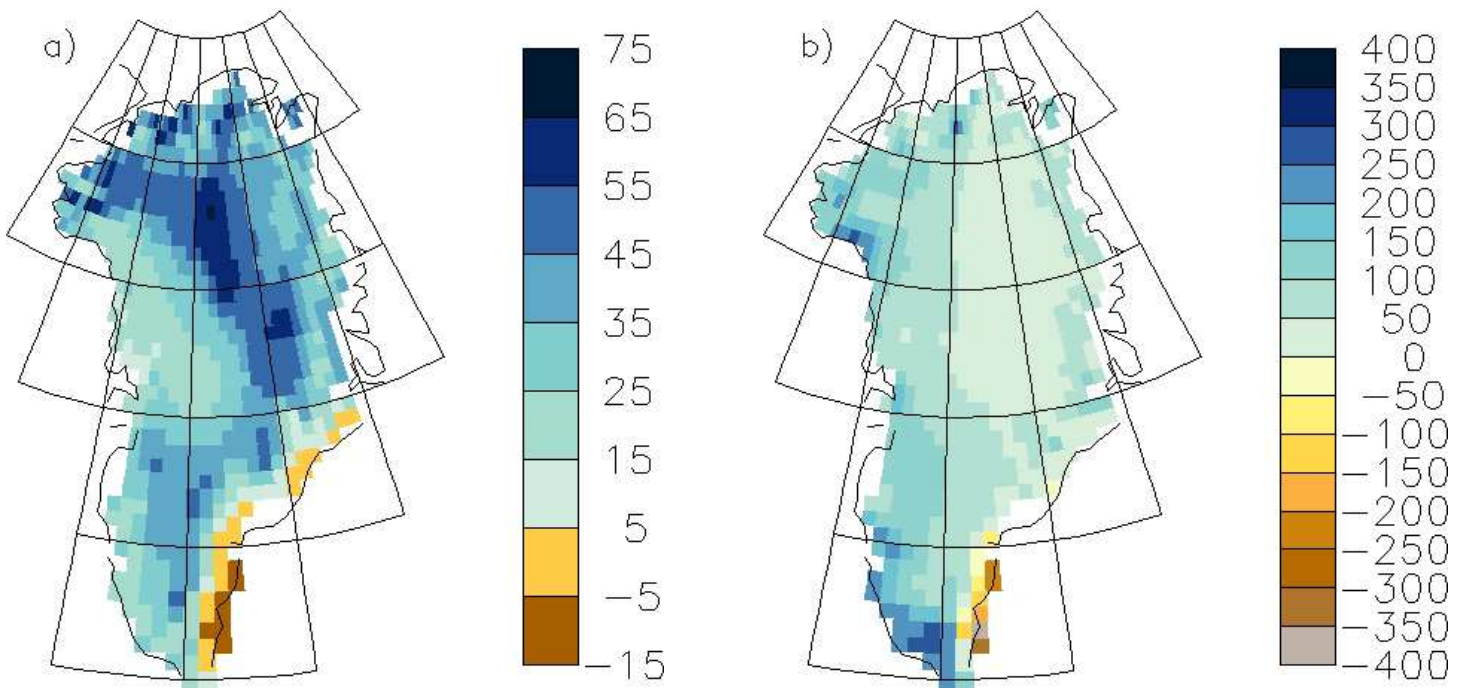

\section{Greenland surface} mass balance at the end of this century

G. Krinner and N. Julien

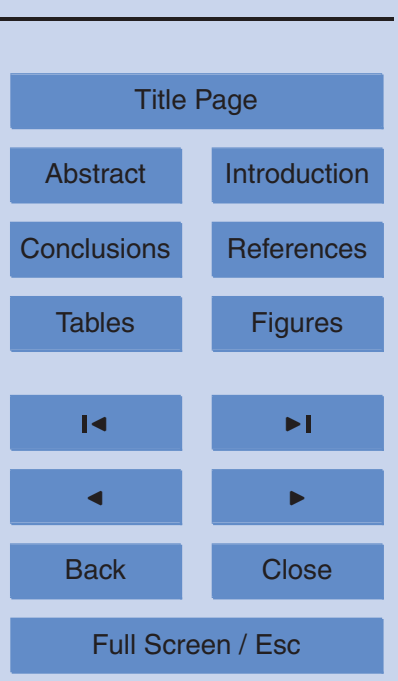

Fig. 7. Precipitation change from 1981-2005 to 2081-2100. (a) Relative change (in \%); (b) Absolute change (in $\mathrm{mm} / \mathrm{yr}$ ). 


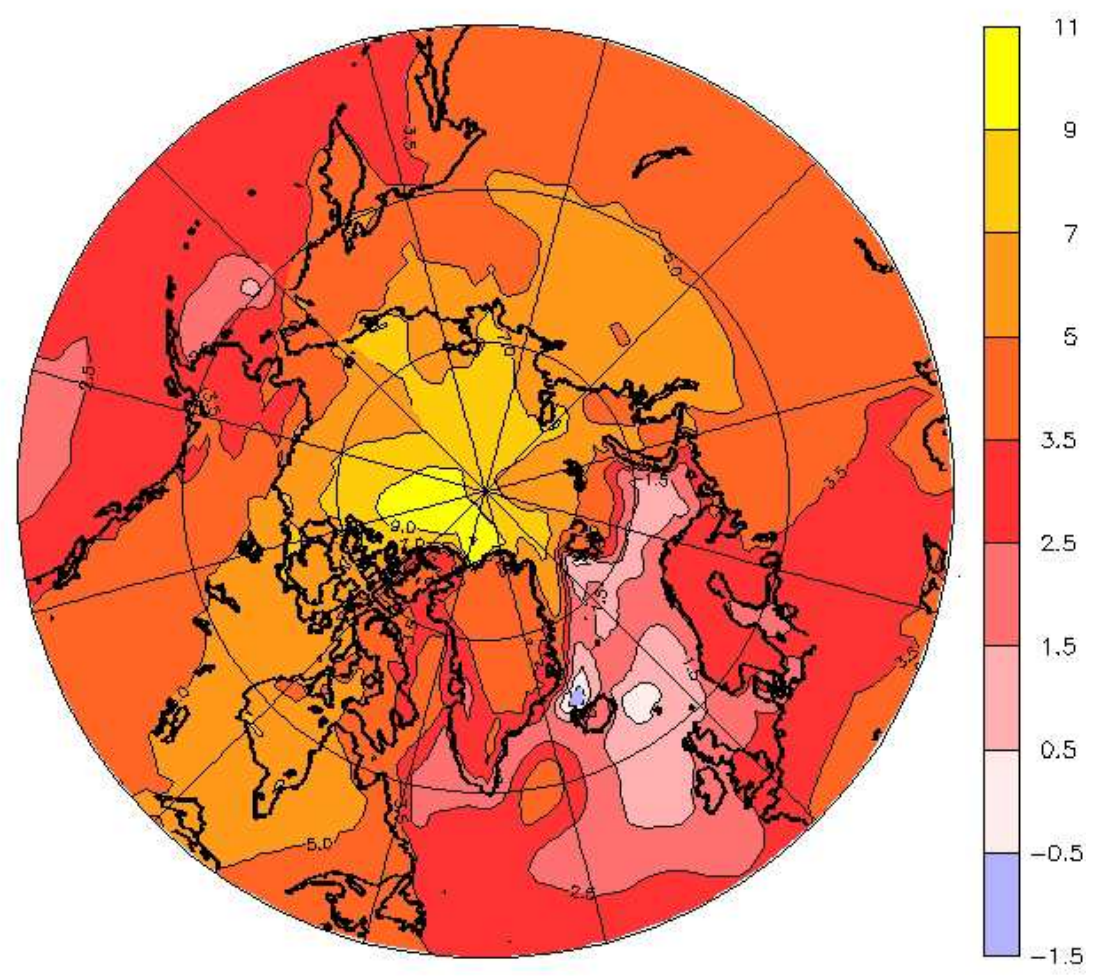

Fig. 8. Annual mean surface air temperature change (in ${ }^{\circ} \mathrm{C}$ ) from $1981-2005$ to $2081-2100$.

\section{TCD}

$1,351-383,2007$

\section{Greenland surface} mass balance at the end of this century

G. Krinner and N. Julien

Title Page

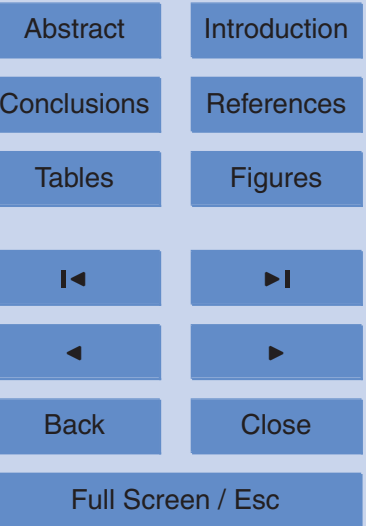

Printer-friendly Version

Interactive Discussion 


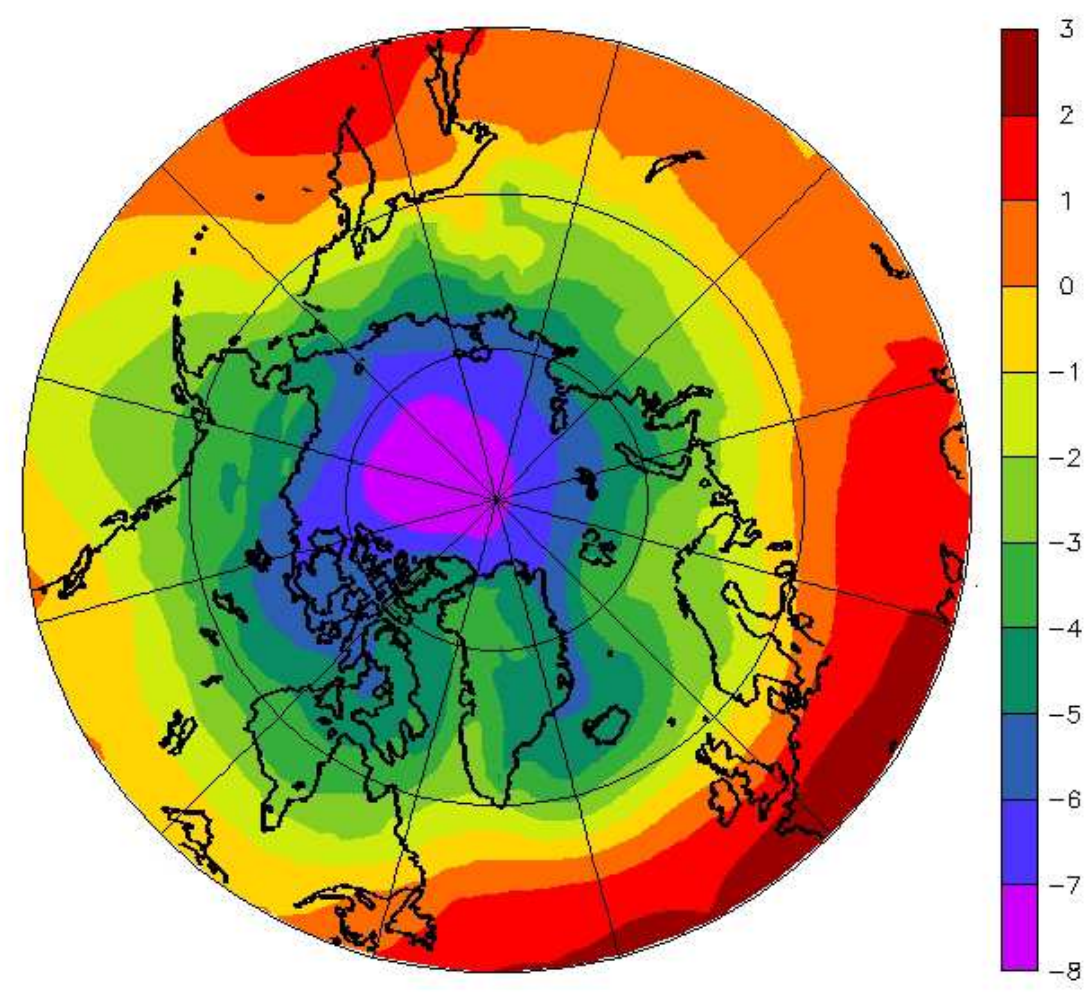

Fig. 9. Difference (in hPa) of the winter (DJF) sea-level pressure from 1981-2005 to 20812100.

\section{TCD}

$1,351-383,2007$

Greenland surface mass balance at the end of this century

G. Krinner and N. Julien

Title Page

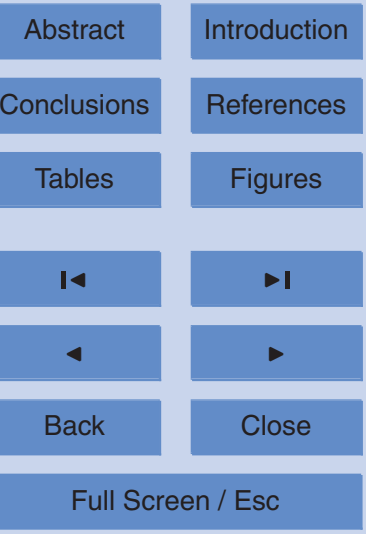

Printer-friendly Version

Interactive Discussion 

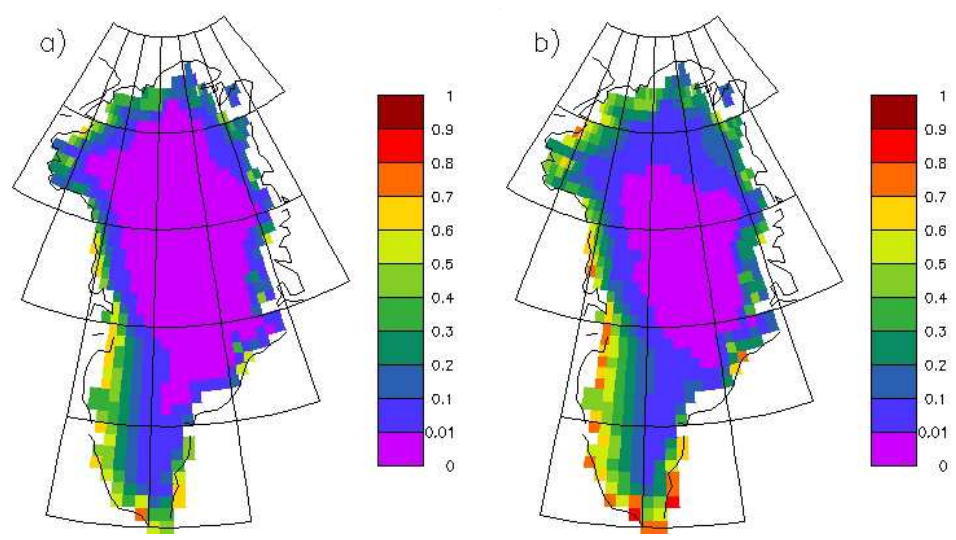

\section{TCD}

$1,351-383,2007$

\section{Greenland surface mass balance at the end of this century}

G. Krinner and N. Julien

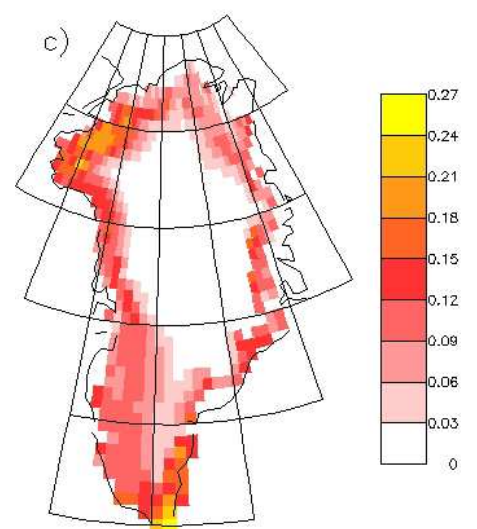

Title Page

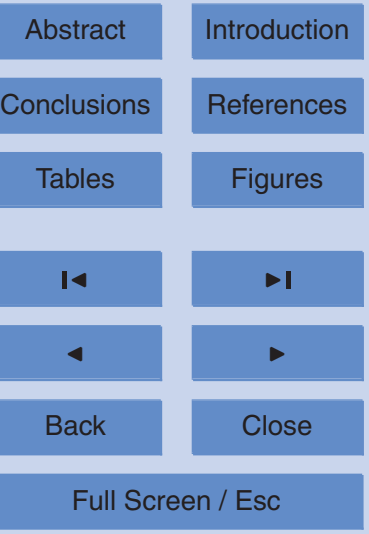

Fig. 10. Fraction of total precipitation that falls as rain (dimensionless). (a) 1981-2005; (b)

Printer-friendly Version 2081-2100; (c) 2081-2100 minus 1981-2005.

Interactive Discussion 

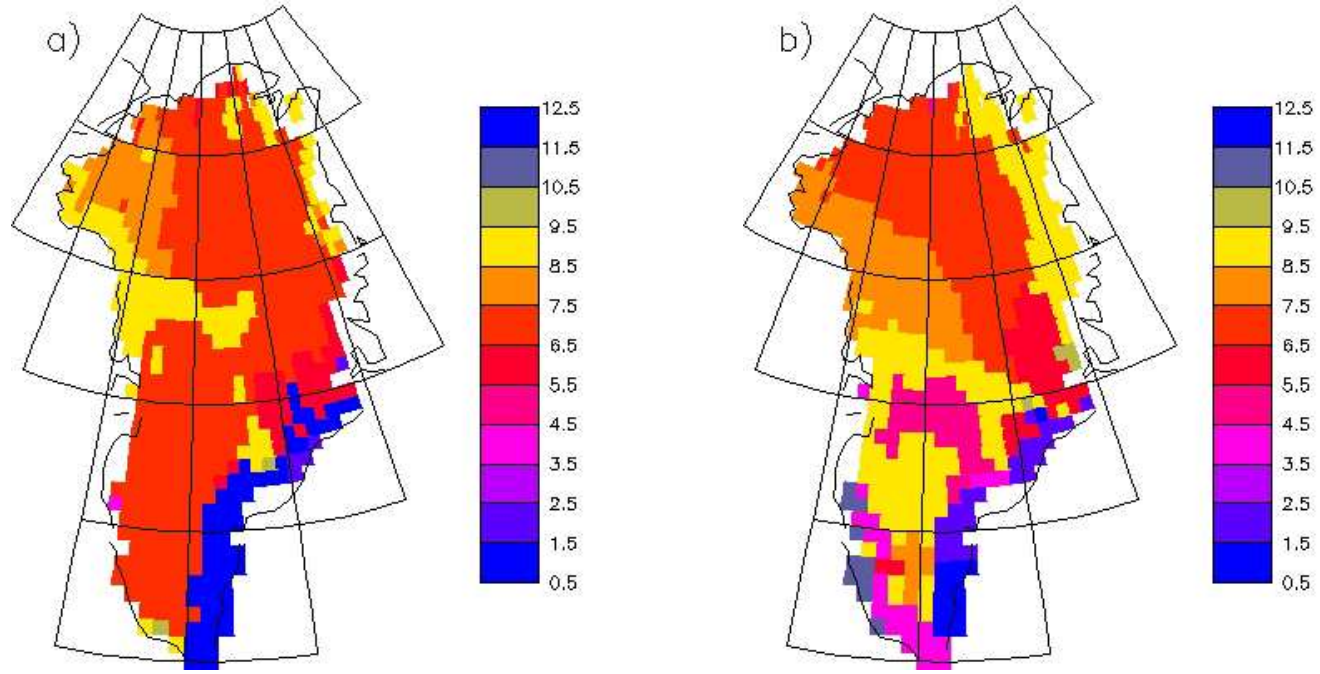

\section{Greenland surface} mass balance at the end of this century

G. Krinner and N. Julien

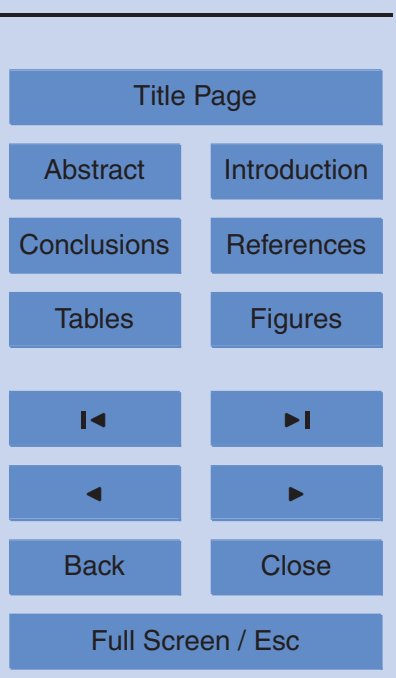

Fig. 11. Precipitation seasonality: Month of maximum precipitation ( $1=$ January, $2=$ February, etc.). (a) 1981-2005 ; (b) 2081-2100. 

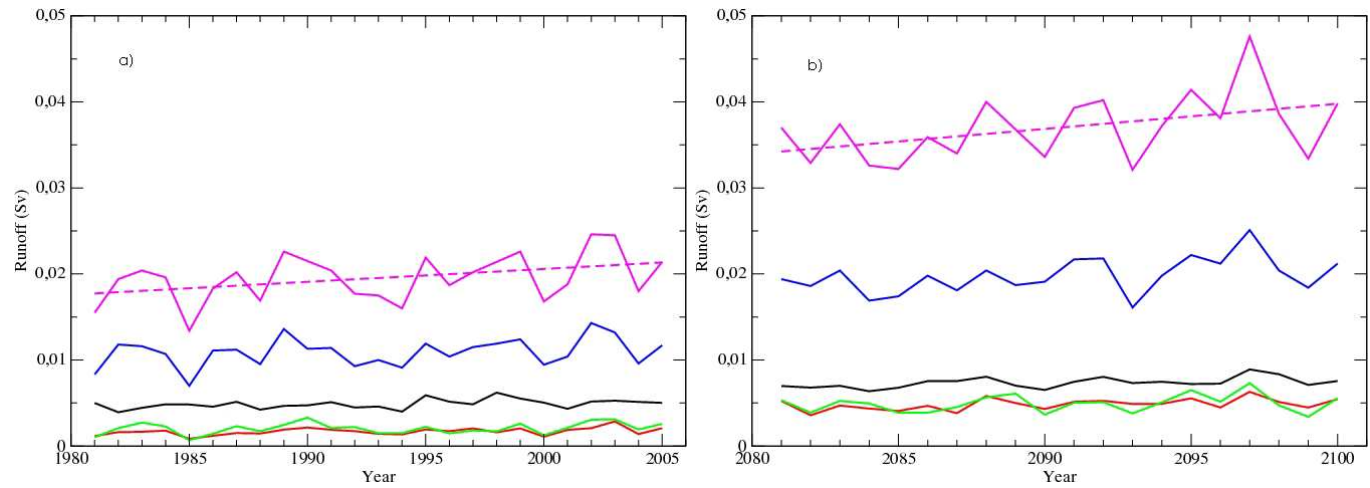

Fig. 12. Simulated runoff from the Greenland ice sheet towards the adjacent seas. (a) 19812005; (b) 2081-2100. Blue: Labrador Sea; black: GIN Seas, south of the Greenland-Iceland sill; red: GIN Seas, north of the Greenland-Iceland sill; green: Arctic Ocean; magenta: total. Linear regression for the total runoff is indicated by the dashed straight line.

\section{Greenland surface mass balance at the end of this century}

G. Krinner and N. Julien

Title Page

Abstract

Introduction

Conclusions

References

Tables

Figures

14

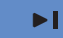

4

Back

Close

Full Screen / Esc

Printer-friendly Version

Interactive Discussion 


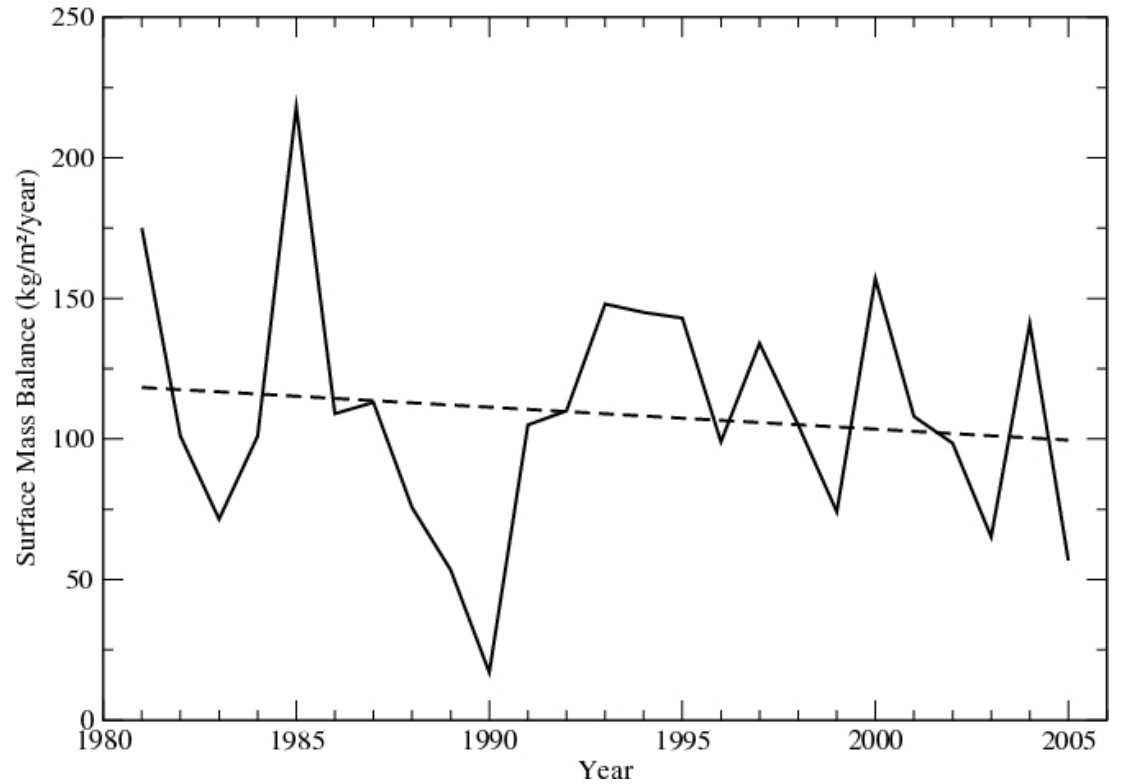

Fig. 13. Simulated annual surface mass balance of the Greenland ice sheet (in $\mathrm{kg} / \mathrm{m}^{2} / \mathrm{yr}$ ) for the period 1981-2005. The linear regression is plotted as a dashed line.

\section{Greenland surface mass balance at the end of this century}

G. Krinner and N. Julien

Title Page

Abstract

Introduction

Conclusions

References

Tables

Figures

14

4 